\title{
Isolation and Pathogenicity of Phytophthora Species from Poplar Plantations in Serbia
}

\author{
Ivan Milenković ${ }^{1,2, *}$, Nenad Keča ${ }^{2}$, Dragan Karadžić ${ }^{2}$, Zlatan Radulović ${ }^{3}$, \\ Justyna A. Nowakowska ${ }^{4}$, Tomasz Oszako ${ }^{5}$, Katarzyna Sikora ${ }^{6}$, Tamara Corcobado ${ }^{1}$ and \\ Thomas Jung 1,7
}

1 Phytophthora Research Centre, Mendel University in Brno, Zemědělská 1, 61300 Brno, Czech Republic; tamicorsa@hotmail.com (T.C.); dr.t.jung@t-online.de (T.J.)

2 Faculty of Forestry, University of Belgrade, Kneza Višeslava 1, 11030 Belgrade, Serbia; nenad.keca@sfb.bg.ac.rs (N.K.); dragan.karadzic@sfb.bg.ac.rs (D.K.)

3 Institute of Forestry, Belgrade, Kneza Višeslava 3, 11030 Belgrade, Serbia; zlatan.radulovic@forest.org.rs

4 Faculty of Biology and Environmental Sciences, Cardinal Stefan Wyszynski University in Warsaw, Wóycickiego 1/3 Street, 01-938 Warsaw, Poland; j.nowakowska@uksw.edu.pl

5 Faculty of Forestry, Białystok University of Technology, Marszałka J. Piłsudskiego 1A, 17-200 Hajnówka, Poland; T.Oszako@ibles.waw.pl

6 Forest Research Institute-IBL, Braci Leśnej 3, 05-090 Raszyn, Poland; K.Sikora@ibles.waw.pl

7 Phytophthora Research and Consultancy, Am Rain 9, 83131 Nussdorf, Germany

* Correspondence: ivan.milenkovic@sfb.bg.ac.rs; Tel.: +38-164-203-1985

Received: 5 May 2018; Accepted: 30 May 2018; Published: 6 June 2018

\begin{abstract}
During a survey in three declining and three healthy poplar plantations in Serbia, six different Phytophthora species were obtained. Phytophthora plurivora was the most common, followed by P. pini, P. polonica, P. lacustris, P. cactorum, and P. gonapodyides. Pathogenicity of all isolated species to four-month and one-year-old cuttings of Populus hybrid clones I-214 and Pánnonia, respectively, was tested using both a soil infestation and stem inoculation test. Isolates of $P$. polonica, $P . \times$ cambivora, P. cryptogea, and $P . \times$ serendipita from other host plants were included as a comparison. In the soil infestation test, the most aggressive species to clone I-214 were P. plurivora, $P$. $\times$ serendipita, and P. pini. On clone Pánnonia, P. gonapodyides and P. pini were the most aggressive, both causing $100 \%$ mortality, followed by P. cactorum, P. $\times$ cambivora, and P. polonica. In the underbark inoculation test, the susceptibility of both poplar clones to the different Phytophthora species was largely similar, as in the soil infestation test, with the exception of $P$. polonica, which proved to be only weakly pathogenic to poplar bark. The most aggressive species to clone I-214 was P. pini, while on clone Pánnonia, the longest lesions and highest disease incidence were caused by P. gonapodyides. Phytophthora cactorum and P. plurivora were pathogenic to both clones, whereas $P$. $\times$ cambivora showed only weak pathogenicity. The implications of these findings and possible pathways of dispersion of the pathogens are discussed.
\end{abstract}

Keywords: soilborne pathogens; pathways; Populus; Phytophthora plurivora; Phytophthora pini; pathogenicity tests

\section{Introduction}

Phytophthora species are fungus-like organisms belonging to the kingdom Chromista (Stramenopiles) within the SAR (Stramenopiles, Alveolata, Rhizaria) super group [1]. These pathogens can infect numerous woody host plants in natural ecosystems, nurseries, and plantings [2-5]. The wide distribution of these damaging pathogens is mainly a consequence of the increasing international trade in living plants resulting in the introduction of non-native Phytophthora spp. into previously unaffected 
regions on infected nursery stock [3-8]. Therefore, forests and plantations established via the planting of nursery stock are at high risk of Phytophthora diseases [4,5].

Poplar plantations are the most widespread, artificially established broadleaved stands in Serbia. In the alluvial plains along the large rivers in Serbia, natural diverse stands of Populus alba L. and P. nigra L. are also common and of high ecological and economic importance. Due to the high productivity rate of the different hybrid clones, the area of poplar plantations in Serbia has increased considerably [9], reaching 48,000 ha or $2.1 \%$ of the total forest area [10]. In the area of Public Enterprise (PE) "Vojvodinašume", poplar plantations along the Sava, Tisa, and Danube rivers are of particular importance. Wet soil conditions and seasonal floodings create favourable conditions for the spread, infection, and survival of Phytophthora species. In riparian poplar plantations along the Sava River and in central Serbia, decline and dieback symptoms indicative of Phytophthora root infections have been recorded during the previous decade. Apart from individual reports of P. cactorum (Lebert and Cohn) Schröter on white poplar in the Czech Republic and in Hungary [4,11], and of $P . \times$ cambivora (Petri) Buisman on poplar trees in Croatia [12], there are no studies of Phytophthora species distribution in poplar stands in Europe. In a preliminary investigation of the fungal and oomycete community associated with poplars in Serbia, P. cactorum and P. plurivora Jung and Burgess were recorded in the rhizosphere of poplar trees [13].

The present study aimed to (1) determine the occurrence and diversity of Phytophthora species in poplar plantations in Serbia; and (2) test the aggressiveness of the isolated Phytophthora spp. to two poplar clones widely used in Serbia.

\section{Material and Methods}

\subsection{Studied Sites}

Four sites were selected near Srem in the northern province of Vojvodina. The 5-33 year old plantations were located on alluvial forest sites with humogley soils along the Sava River and belonged to Public Enterprise (PE) “Vojvodinašume" (Table 1). In stands 1 and 2, poplars showed increased crown transparency and yellowing of leaves (Figure 1a,b), while stands 3 and 4 were healthy. Two additional sites were located in central Serbia, in the forests of PE "Srbijašume" (stand $5 ; 25$ years old) and in a private property in the village Brzeće, near the Kopaonik mountain (stand 6; 2 years old), respectively (Table 1). The latter two stands showed severe dieback and mortality (Figure 1c,d). Due to their vicinity to local rivers, both stands were growing on wet alluvial soils. All six plantations were established via the planting of nursery stock. In four plantations, poplar clone $P . \times$ euramericana I-214, a hybrid between P. nigra and the North American P. deltoides Bartram ex. Marshall, was used, while the other two plantations contained P. deltoides (Table 1).

Table 1. Isolation of Phytophthora species from rhizosphere soil samples in poplar plantations in Serbia.

\begin{tabular}{|c|c|c|c|c|c|c|c|}
\hline $\begin{array}{l}\text { Stand, Location } \\
\text { (River) }\end{array}$ & Tree No. & $\begin{array}{c}\text { Populus } \\
\text { Species/Clone }\end{array}$ & Age & $\begin{array}{c}\text { Disease } \\
\text { Symptoms }\end{array}$ & Sample & $\begin{array}{l}\text { Phytophthora } \\
\text { Species (No. } \\
\text { Isolates) }\end{array}$ & $\begin{array}{l}\text { GenBank } \\
\text { Accession } \\
\text { Numbers }\end{array}$ \\
\hline \multirow{5}{*}{$\begin{array}{l}\text { Stand No. 1, Klenak } \\
44^{\circ} 45^{\prime} 48^{\prime \prime} \text { N } 19^{\circ} 48^{\prime} 18^{\prime \prime} \\
\text { E } 86 \mathrm{~m} \text { asl (Sava } \\
\text { River) }\end{array}$} & 1 & $\begin{array}{l}\text { Populus } \\
\text { deltoides }\end{array}$ & 10 & No symptoms & Rhizosphere soil & $\begin{array}{l}\text { P. plurivora } \\
\text { P. cactorum }\end{array}$ & \\
\hline & 2 & P. deltoides & 10 & No symptoms & Wet rhizosphere soil & P. lacustris & \\
\hline & 3 & P. deltoides & 10 & No symptoms & Wet rhizosphere soil & P. gonapodyides & \\
\hline & 5 & P. deltoides & 10 & No symptoms & Wet rhizosphere soil & P. gonapodyides & \\
\hline & 6 & P. deltoides & 10 & No symptoms & Rhizosphere soil & - & \\
\hline
\end{tabular}


Table 1. Cont

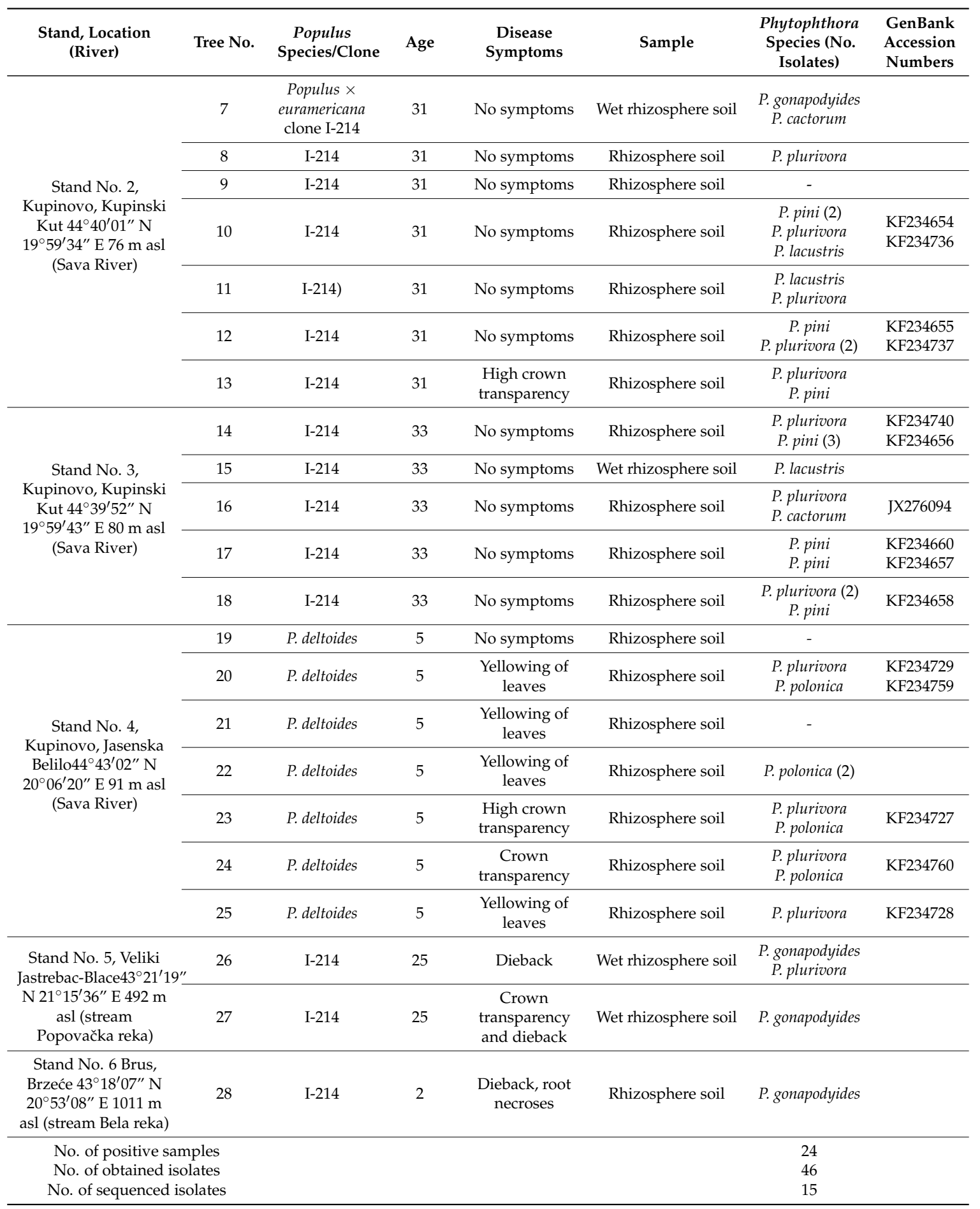



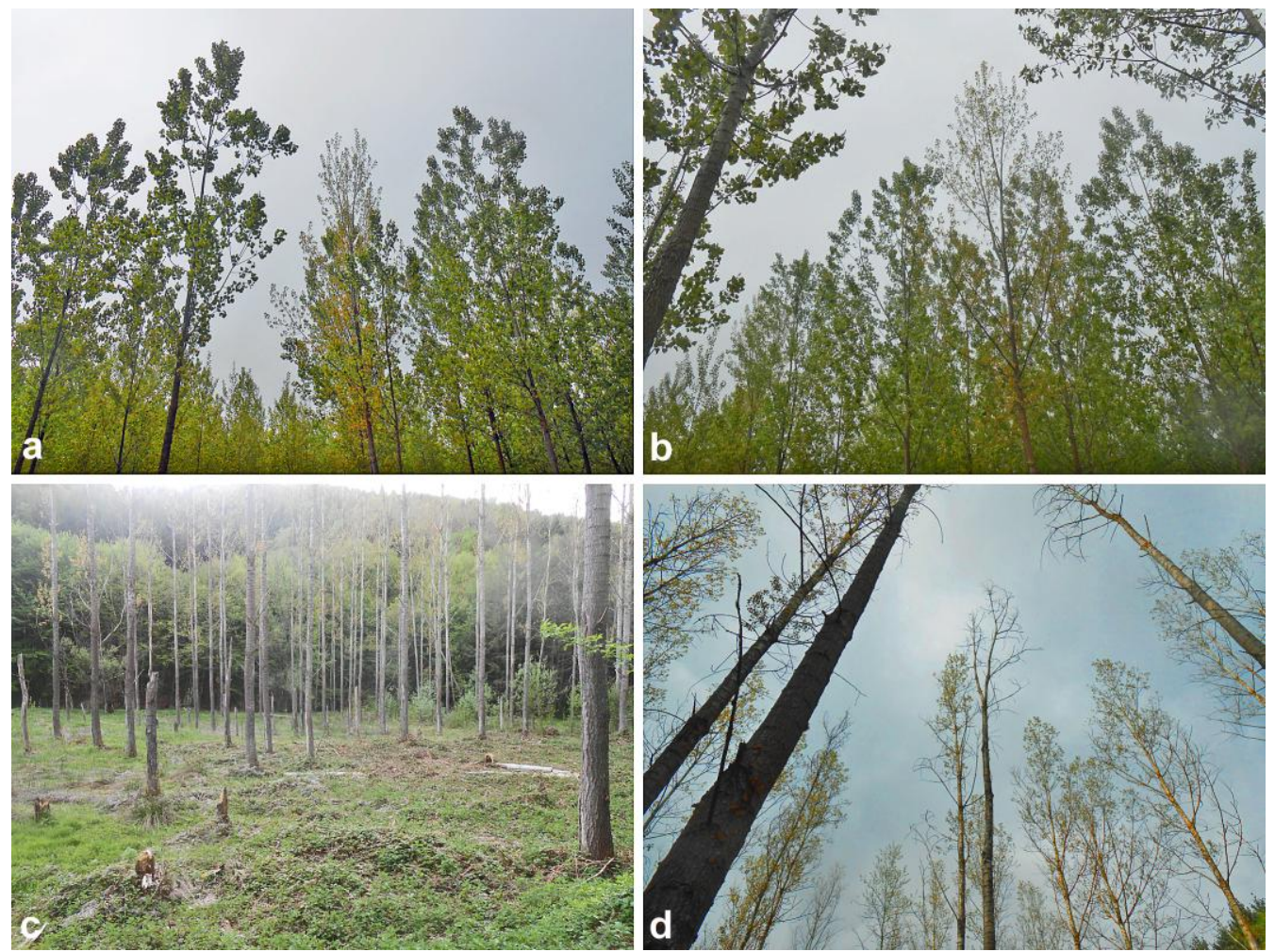

Figure 1. Disease symptoms in poplar plantations in Serbia: $(\mathbf{a}, \mathbf{b})$ increased crown transparency and yellowing of leaves on five-year old trees of Populus deltoides in stand No. 4; (c,d) severe mortality and dieback of 25-years old trees of Populus $\times$ euramericana clone I-214 in stand No. 5 .

\subsection{Sampling, Isolation, and Morphological Identification of Phytophthora Spp.}

Sampling and isolation methodology were performed according to [14,15]. In the four plantations in the Srem forest area, 25 poplar trees were randomly sampled in May 2011 and May/June 2012, while in the two stands in central Serbia, three trees were sampled in the spring and summer 2017. Three to four soil monoliths were taken from the rhizosphere of each tree, mixed, and ca. 3-4 L of soil per tree was taken to the laboratory. Both symptomatic and asymptomatic trees were sampled. Each soil sample was thoroughly mixed and a subsample of ca. $200 \mathrm{~mL}$ used for the isolation test using young leaves of Quercus robur L. and Fagus sylvatica L., as baits. The baiting test was performed at $20^{\circ} \mathrm{C}$ and natural light. After the appearance of the first necrotic spots, baiting leaves were examined for the presence of Phytophthora sporangia under the light microscope. Small pieces from the necroses were then plated onto selective PARPNH agar [14-16]. First hyphae from plated leaves were subcultured onto V8-agar (V8A) and carrot juice agar (CA) $(800 \mathrm{~mL}$ distilled water, $200 \mathrm{~mL}$ carrot or vegetable juice (Biotta ${ }^{\circledR}$, Tägerwilen, Switzerland), $18 \mathrm{~g}$ agar (Torlak, Belgrade, Serbia) and $3 \mathrm{~g} \mathrm{CaCO}_{3}$; [15]), and stored at $20{ }^{\circ} \mathrm{C}$ for further examinations.

For classical species identification, the morphology of obtained isolates was examined at $\times 400$ magnifications using a light microscope (CETI ${ }^{\circledR}$ MAGNUM-T/Trinocular Microscope, Oxon, UK). Structures were measured using a camera $\left(\mathrm{Si} 3000^{\circledR}\right.$, Medline Scientific, Oxon, UK) and the XliCap ${ }^{\circledR}(\mathrm{Xl}$ Imaging Ltd., Swansea, UK) imaging software. Sporangia were produced by flooding agar discs of young CA colonies for 24-48 $\mathrm{h}$ in non-sterile soil extract according to [14]. Gametangia were studied from four-week-old CA cultures, incubated at $20-22{ }^{\circ} \mathrm{C}$ in the dark. Self-sterile isolates were paired with known tester strains of P. cryptogea Pethybridge and Lafferty (A1 mating type: BBA 65909; A2 mating type: BBA 63651) to clarify whether they were sterile or heterothallic, and to which mating type heterothallic isolates belong. Colony growth patterns were examined after the growth of isolates for one week at $20^{\circ} \mathrm{C}$ in the dark on four different agar media, including CA, V8A, malt-extract-agar 
(MEA; 48 g/L malt-extract-agar; Merck KGaA, Darmstadt, Germany), and potato-dextrose-agar (PDA; $39 \mathrm{~g} / \mathrm{L}$ potato-dextrose-agar; Merck KGaA, Darmstadt, Germany). Morphological features and colony growth patterns were compared with descriptions in the literature [2,17-22].

\subsection{Molecular identifIcation of Phytophthora Spp.}

The ITS1-5.8S-ITS2 rDNA region of 15 selected isolates representative of all morphotypes was sequenced after direct PCR using Phire ${ }^{\mathrm{TM}}$ Plant Direct PCR Kits (Thermo Fisher Scientific Inc., Waltham, MA, USA). Mycelium from three to five days old V8A colonies was scraped without agar using a sterile needle and placed in $2 \mathrm{~mL}$ Eppendorf tubes, with $30 \mu \mathrm{L}$ of previously added Dilution Buffer (Thermo Fisher Scientific Inc., Waltham, MA, USA). PCR reactions were performed with a $20 \mu \mathrm{L}$ volume, containing $10 \mu \mathrm{L} 1 \times$ Phire Plant PCR Buffer-a, $1 \mu \mathrm{L} 0.5 \mu \mathrm{M}$ of primers ITS4/ITS6 [23,24], $0.4 \mu \mathrm{L}$ Phire Hot Start II DNA Polymerase, $0.5 \mu \mathrm{L}$ of Dilution Buffer with diluted young hypha, and water (mQ) up to $20 \mu \mathrm{L}$, according to the manufacturer's recommendation. Reactions were performed in a PTC-200TM machine (MJ Research Inc., Waltham, MA, USA) with three-step PCR protocol, according to the manufacturer's recommendations. The PCR program was $5 \mathrm{~min}$ at $98{ }^{\circ} \mathrm{C}$ followed by 40 cycles of $5 \mathrm{~s}$ at $98^{\circ} \mathrm{C}, 5 \mathrm{~s}$ at $55^{\circ} \mathrm{C}$, and $50 \mathrm{~s}$ at $72{ }^{\circ} \mathrm{C}$. The presence and size of PCR products was confirmed by analyzing $1 \mu \mathrm{L}$ of product by electrophoresis in 1\% TAE-agarose gel, stained with GelRed ${ }^{\mathrm{TM}}$ Nulceid Acid Dye (Biotium, Inc., Fremont, CA, USA), with FastRuler MR DNA Ladder (Thermo Fisher Scientific, Waltham, MA, USA) as the molecular mass standard of DNA. For sequencing, $20 \mu \mathrm{L}$ PCR product was purified with the CleanUp Kit (A\&A Biotechnology, Gdynia, Poland), following the manufacturer's protocol, and sequenced with ABI 3730xl DNA Analyzer (Applied Biosystems, Foster City, CA, USA). Obtained sequences were aligned using the ClustalW algorithm of the BioEdit program subjected to an NCBI BLAST search (http: / / www.ncbi.nlm.nih.gov/BLAST/). Sequence analysis was done with MEGA6 software [25]. Isolates were assigned to a Phytophthora species when sequence identities were above a 99\% cut-off in respect to those of extype isolates or key isolates. All ITS sequences obtained in this study were submitted to GenBank (Table 1).

\subsection{Soil Infestation Test}

One-year old cuttings of P. $\times$ euramericana clones I-214 and Pánnonia, commonly used in Serbian forestry, were rooted and grown for four months in the laboratory at $22-25{ }^{\circ} \mathrm{C}$ and natural daylight in 151 plastic containers containing an autoclaved mixture of peat (Florabella, AGRO-FertiCrop d.o.o., Subotica, Serbia) and perlite (4-6 mm; Agro Perlit Extra, Termika, Zrenjanin, Serbia) with a 3:1 volume ratio. Isolates of all Phytophthora species recovered from the rhizosphere of poplar trees in this study, and, for comparisons, each isolate of P. polonica Belbahri et al. from Q. robur, P. cryptogea from Q. petraea (Matt.) Liebl., P. $\times$ cambivora from F. sylvatica, and $P . \times$ serendipita Man in't Veld et al. from Pyrus pyraster (L.) Burgsd. were included (Table 2). Twelve plants per clone and per treatment and control were used (Table 2). Inocula of 12 isolates from nine different Phytophthora species were prepared using fine vermiculite, millet seeds, and V8 juice [14]. The substrate in the controls received a sterile mixture of fine vermiculite, millet seeds, and V8 juice [14]. After the inoculation, plants were immediately flooded for $72 \mathrm{~h}$, and flooding was repeated at three-week intervals. After each flooding period, the water was removed and sterilized with bleach. During the second and third flooding, leaves of Prunus laurocerasus L. and $Q$. robur were floated on the water surface in order to check the ability of the Phytophthora strains to produce sporangia and cause infections. 
Table 2. Pathogenicity of nine Phytophthora species to Populus $\times$ euramericana clones I-214 and Pánnonia in the soil infestation test after 10 weeks.

\begin{tabular}{|c|c|c|c|c|c|c|c|c|}
\hline \multirow{2}{*}{$\begin{array}{l}\text { Poplar } \\
\text { Clone }\end{array}$} & \multirow{2}{*}{$\begin{array}{c}\text { Phytophthora } \\
\text { Species } \\
\text { (Isolates) }\end{array}$} & \multirow{2}{*}{$\begin{array}{c}\text { No. of } \\
\text { Inoculated } \\
\text { Plants }\end{array}$} & \multirow{2}{*}{$\begin{array}{l}\text { No. of } \\
\text { Dead } \\
\text { Plants }\end{array}$} & \multirow{2}{*}{$\begin{array}{c}\text { No. of Plants } \\
\text { with Bark } \\
\text { Necroses }\end{array}$} & \multirow{2}{*}{$\begin{array}{c}\text { No. of Plants } \\
\text { with } 100 \% \\
\text { Root Rot }\end{array}$} & \multirow{2}{*}{$\begin{array}{c}\text { Dry } \\
\text { Weight } \\
\text { of Small } \\
\text { Roots (g) }\end{array}$} & \multicolumn{2}{|c|}{$\begin{array}{c}\text { Re-Isolation } \\
\text { Frequency (\%) }\end{array}$} \\
\hline & & & & & & & Necroses & $\begin{array}{l}\text { Fine } \\
\text { Roots }\end{array}$ \\
\hline \multirow{13}{*}{$\mathrm{I}-214$} & Control & 12 & 0 & 0 & 0 & 3.591 & 0 & 0 \\
\hline & $\begin{array}{l}\text { P. cactorum } \\
\text { (JX276094) }\end{array}$ & 12 & 8 & $2^{2}$ & 9 & 2.073 & 100 & 100 \\
\hline & $\begin{array}{l}\text { P. cryptogea } \\
\text { (KF234765) }\end{array}$ & 12 & 7 & $1^{\mathrm{a}} ; 2^{\mathrm{b}}$ & 9 & 2.199 & 100 & 100 \\
\hline & $\begin{array}{l}\text { P. gonapodyides } \\
\text { (2011/Pop.04) }\end{array}$ & 12 & 9 & $1^{\mathrm{a}} ; 1^{\mathrm{b}}$ & 10 & 1.506 & 83.3 & 100 \\
\hline & $\begin{array}{c}\text { P. lacustris } \\
\text { (2011/Pop.Blato.03) }\end{array}$ & 12 & 9 & $2^{a} ; 1^{b}$ & 10 & 1.59 & 66.67 & 100 \\
\hline & $\begin{array}{c}\text { P.pini } \\
\text { (KF234655) }\end{array}$ & 12 & 10 & $2^{a}$ & 9 & 1.155 & 100 & 100 \\
\hline & $\begin{array}{c}\text { P.pini } \\
\text { (KF234658) }\end{array}$ & 12 & 10 & $3^{a}$ & 10 & 1.143 & 100 & 100 \\
\hline & $\begin{array}{l}\text { P. plurivora } \\
\text { (KF234737) }\end{array}$ & 12 & 7 & $4^{\mathrm{a}} ; 1^{\mathrm{b}}$ & 10 & 1.092 & 100 & 100 \\
\hline & $\begin{array}{l}\text { P. plurivora } \\
\text { (KF234740) }\end{array}$ & 12 & 11 & $3^{a}$ & 11 & 1.26 & 100 & 83.3 \\
\hline & $\begin{array}{l}\text { P. polonica } \\
\text { (JX276065) }\end{array}$ & 12 & 9 & $2^{\mathrm{a}} ; 1^{\mathrm{b}}$ & 9 & 1.542 & 100 & 100 \\
\hline & $\begin{array}{c}\text { P. polonica } \\
\text { (KF234760) }\end{array}$ & 12 & 6 & $4^{\mathrm{a}} ; 1^{\mathrm{b}}$ & 8 & 1.773 & 100 & 100 \\
\hline & $\begin{array}{l}\text { P. } \times \text { cambivora } \\
(\mathrm{JX} 276088)\end{array}$ & 12 & 5 & $4^{\mathrm{a}}$ & 5 & 2.112 & 100 & 100 \\
\hline & $\begin{array}{l}\text { P. } \times \text { serendipita } \\
(\mathrm{KM} 272262)\end{array}$ & 12 & 11 & $2^{a}$ & 10 & 2.199 & 100 & 100 \\
\hline \multirow{13}{*}{ Pánnonia } & Control & 12 & 0 & 0 & 0 & 4.014 & 0 & 0 \\
\hline & $\begin{array}{l}\text { P. cactorum } \\
\text { (JX276094) }\end{array}$ & 12 & 10 & $1^{\mathrm{a}} ; 1^{\mathrm{b}}$ & 4 & 1.245 & 100 & 100 \\
\hline & $\begin{array}{l}\text { P. cryptogea } \\
\text { (KF234765) }\end{array}$ & 12 & 9 & $1^{b}$ & 10 & 1.239 & 100 & 100 \\
\hline & $\begin{array}{l}\text { P. gonapodyides } \\
\text { (2011/Pop.04) }\end{array}$ & 12 & 12 & 0 & 12 & 1.02 & 100 & 100 \\
\hline & $\begin{array}{c}\text { P. lacustris } \\
\text { (2011/Pop.Blato.03) }\end{array}$ & 12 & 8 & $2^{\mathrm{a}} ; 1^{\mathrm{b}}$ & 9 & 1.209 & 50 & 100 \\
\hline & $\begin{array}{c}\text { P. pini } \\
\text { (KF234655) }\end{array}$ & 12 & 9 & $2^{b}$ & 11 & 1.509 & 100 & 100 \\
\hline & $\begin{array}{c}\text { P.pini } \\
\text { (KF234658) }\end{array}$ & 12 & 12 & 0 & 12 & 1.077 & 100 & 100 \\
\hline & $\begin{array}{l}\text { P. plurivora } \\
\text { (KF234737) }\end{array}$ & 12 & 7 & $3^{\mathrm{a}} ; 1^{\mathrm{b}}$ & 8 & 1.158 & 100 & 100 \\
\hline & $\begin{array}{l}\text { P. plurivora } \\
\text { (KF234740) }\end{array}$ & 12 & 7 & $3^{\mathrm{a}} ; 2^{\mathrm{b}}$ & 9 & 1.357 & 100 & 100 \\
\hline & $\begin{array}{l}\text { P. polonica } \\
\text { (JX276065) }\end{array}$ & 12 & 10 & $2^{a}$ & 10 & 1.626 & 100 & 100 \\
\hline & $\begin{array}{l}\text { P. polonica } \\
\text { (KF234760) }\end{array}$ & 12 & 10 & $1^{b}$ & 10 & 1.434 & 100 & 100 \\
\hline & $\begin{array}{l}\text { P. } \times \text { cambivora } \\
(\mathrm{JX} 276088)\end{array}$ & 12 & 10 & $1^{b}$ & 9 & 1.359 & 100 & 91.67 \\
\hline & $\begin{array}{l}\text { P. } \times \text { serendipita } \\
(\mathrm{KM} 272262)\end{array}$ & 12 & 9 & $3^{a}$ & 11 & 1.131 & 100 & 100 \\
\hline
\end{tabular}


The experiment was performed in the laboratory at $22-25^{\circ} \mathrm{C}$ and natural daylight. After ten weeks and three flooding periods, all plants were carefully excavated and the roots washed. Photos were taken and re-isolations were made by plating small pieces from the edges of necrotic lesions and segments of fine roots from each infested and control plant onto PARPNH. Then, all roots were harvested from the cuttings, dried at $65^{\circ} \mathrm{C}$ for $72 \mathrm{~h}$, and their dry weight measured using a fine scale (Exacta 300 EB, Tehtnica, Železniki, Slovenia).

\subsection{Underbark Inoculation Test}

One-year-old cuttings of $P . \times$ euramericana clones I-214 and Pánnonia were grown for one year in an autoclaved mixture of peat (Florabella, AGRO-FertiCrop d.o.o., Subotica, Serbia) and perlite (4-6 mm; Agro Perlit Extra, Termika, Serbia) with a 2:1 volume ratio. After sterilising the bark at a 10-15 cm distance from the collar with $70 \%$ ethanol, the cuttings were inoculated under the bark using a sterile 7-mm metal cork borer. Same-sized plugs cut from the edges of three to five -day old CA colonies, were used as inocula. In total, ten isolates of seven different Phytophthora species were used (Table 3), including isolates of all Phytophthora species recovered from the rhizosphere of poplar trees in this study, and, as comparisons, one isolate each of P. polonica from Q. robur and $P$. $\times$ cambivora from F. sylvatica. Control plants were inoculated with sterile CA plugs. The agar plugs were covered with the removed piece of bark and sterile moistened cotton, and sealed with Parafilm (Merck KGaA, Darmstadt, Germany). The plants were incubated in the laboratory at $22-25^{\circ} \mathrm{C}$ and natural daylight, and checked weekly for the appearance of symptoms. After 11 weeks, the experiment was finished and necroses lengths were recorded after removal of the outer bark. Reisolations were made from all the inoculated and control plants by plating small pieces from the upper and lower margins of necrotic lesions or, in the absence of necroses, from the margins of the inoculation places onto PARPNH. Measuring of necrosis length was performed using a precise ruler, while necrosis width was measured using a flexible measurement tape.

Table 3. Results of the underbark inoculation test with Populus $\times$ euramericana clones I-214 and Pánnonia and seven Phytophthora spp. after 11 weeks.

\begin{tabular}{|c|c|c|c|c|c|c|c|c|}
\hline $\begin{array}{l}\text { Poplar } \\
\text { Clone }\end{array}$ & $\begin{array}{c}\text { Phytophthora } \\
\text { Species } \\
\text { (Isolates) }\end{array}$ & $\begin{array}{l}\text { Number of } \\
\text { Inoculated } \\
\text { Plants }\end{array}$ & $\begin{array}{c}\text { Stem } \\
\text { Diameter }\left(x^{-}\right. \\
\pm S E(m m))\end{array}$ & $\begin{array}{l}\text { Plant Height } \\
\left(\mathrm{x}^{-} \pm \mathrm{SE}\right. \\
(\mathrm{mm}))\end{array}$ & $\begin{array}{c}\text { Number of } \\
\text { Plants with } \\
\text { Lesions } \\
\text { (Bleeding) }\end{array}$ & $\begin{array}{c}\text { Number of } \\
\text { Plants with } \\
\text { Secondary } \\
\text { Shoots at } \\
\text { Necroses } \\
\text { Margins }\end{array}$ & $\begin{array}{c}\text { Number } \\
\text { of Plants } \\
\text { with } \\
\text { Dieback }\end{array}$ & $\begin{array}{l}\text { Reisolation } \\
\text { Frequency } \\
\quad(\%)\end{array}$ \\
\hline \multirow{11}{*}{$\mathrm{I}-214$} & Control & 12 & $10.6 \pm 0.29$ & $103.6 \pm 3.16$ & 0 & 0 & 0 & 0 \\
\hline & $\begin{array}{l}\text { P. cactorum } \\
\text { (JX276094) }\end{array}$ & 12 & $9.3 \pm 0.26$ & $95.7 \pm 3.47$ & $12(9)$ & 2 & 0 & 100 \\
\hline & $\begin{array}{l}\text { P. gonapodyides } \\
\text { (2011/Pop.04) }\end{array}$ & 12 & $9.7 \pm 0.21$ & $93.7 \pm 2.74$ & $12(2)$ & 0 & 0 & 83.3 \\
\hline & $\begin{array}{c}\text { P. lacustris } \\
\text { (2011/Pop.Blato.03) }\end{array}$ & 12 & $9.1 \pm 0.36$ & $90.1 \pm 3.72$ & $12(3)$ & 0 & 0 & 83.3 \\
\hline & $\begin{array}{c}\text { P. pini } \\
\text { (KF234655) }\end{array}$ & 12 & $11.2 \pm 0.49$ & $103.8 \pm 3.58$ & $12(8)$ & 5 & 5 & 100 \\
\hline & $\begin{array}{c}\text { P. pini } \\
\text { (KF234658) }\end{array}$ & 12 & $10.6 \pm 0.31$ & $100.2 \pm 2.16$ & $12(11)$ & 10 & 1 & 100 \\
\hline & $\begin{array}{l}\text { P. plurivora } \\
\text { (KF234737) }\end{array}$ & 12 & $9.3 \pm 0.34$ & $89 \pm 3.02$ & $12(6)$ & 0 & 1 & 100 \\
\hline & $\begin{array}{l}\text { P. plurivora } \\
\text { (KF234740) }\end{array}$ & 12 & $10.1 \pm 0.3$ & $100.5 \pm 3.49$ & $12(9)$ & 4 & 1 & 100 \\
\hline & $\begin{array}{l}\text { P. polonica } \\
\text { (JX276065) }\end{array}$ & 12 & $9.3 \pm 0.22$ & $94.1 \pm 2.57$ & $7(0)$ & 0 & 0 & 91.67 \\
\hline & $\begin{array}{l}\text { P. polonica } \\
\text { (KF234760) }\end{array}$ & 12 & $10.1 \pm 0.37$ & $95.7 \pm 2.15$ & $9(0)$ & 0 & 0 & 100 \\
\hline & $\begin{array}{l}\text { P. } \times \text { cambivora } \\
(\text { JX276088) }\end{array}$ & 12 & $9.8 \pm 0.51$ & $100.6 \pm 3.87$ & $10(0)$ & 1 & 0 & 58.3 \\
\hline
\end{tabular}


Table 3. Cont.

\begin{tabular}{|c|c|c|c|c|c|c|c|c|}
\hline $\begin{array}{l}\text { Poplar } \\
\text { Clone }\end{array}$ & $\begin{array}{c}\text { Phytophthora } \\
\text { Species } \\
\text { (Isolates) }\end{array}$ & $\begin{array}{l}\text { Number of } \\
\text { Inoculated } \\
\text { Plants }\end{array}$ & $\begin{array}{c}\text { Stem } \\
\text { Diameter }\left(x^{-}\right. \\
\pm S E(m m))\end{array}$ & $\begin{array}{l}\text { Plant Height } \\
\left(\mathrm{x}^{-} \pm \mathrm{SE}\right. \\
(\mathrm{mm}))\end{array}$ & $\begin{array}{c}\text { Number of } \\
\text { Plants with } \\
\text { Lesions } \\
\text { (Bleeding) }\end{array}$ & $\begin{array}{c}\text { Number of } \\
\text { Plants with } \\
\text { Secondary } \\
\text { Shoots at } \\
\text { Necroses } \\
\text { Margins }\end{array}$ & $\begin{array}{c}\text { Number } \\
\text { of Plants } \\
\text { with } \\
\text { Dieback }\end{array}$ & $\begin{array}{l}\text { Reisolation } \\
\text { Frequency } \\
\quad(\%)\end{array}$ \\
\hline \multirow{11}{*}{ Pánnonia } & Control & 12 & $9.4 \pm 0.56$ & $110.7 \pm 5.74$ & 0 & 0 & 0 & 0 \\
\hline & $\begin{array}{l}\text { P. cactorum } \\
\text { (JX276094) }\end{array}$ & 12 & $10.9 \pm 0.64$ & $111.2 \pm 6.11$ & $12(2)$ & 3 & 2 & 100 \\
\hline & $\begin{array}{l}\text { P. gonapodyides } \\
\text { (2011/Pop.04) }\end{array}$ & 12 & $9.9 \pm 0.4$ & $118 \pm 5.48$ & $12(2)$ & 0 & 7 & 91.67 \\
\hline & $\begin{array}{c}\text { P. lacustris } \\
\text { (2011/Pop.Blato.03) }\end{array}$ & 12 & $7.9 \pm 0.28$ & $74.8 \pm 2.27$ & $12(3)$ & 5 & 0 & 66.67 \\
\hline & $\begin{array}{c}\text { P. pini } \\
\text { (KF234655) }\end{array}$ & 12 & $9.9 \pm 0.42$ & $103.7 \pm 4.49$ & $12(6)$ & 0 & 1 & 100 \\
\hline & $\begin{array}{c}\text { P. pini } \\
\text { (KF234658) }\end{array}$ & 12 & $9.8 \pm 0.55$ & $113 \pm 7.39$ & $12(4)$ & 2 & 1 & 100 \\
\hline & $\begin{array}{l}\text { P. plurivora } \\
\text { (KF234737) }\end{array}$ & 12 & $8.4 \pm 0.29$ & $98.6 \pm 6.06$ & $12(7)$ & 0 & 0 & 100 \\
\hline & $\begin{array}{l}\text { P. plurivora } \\
\text { (KF234740) }\end{array}$ & 12 & $9.9 \pm 0.56$ & $114.1 \pm 6.01$ & $12(5)$ & 0 & 1 & 100 \\
\hline & $\begin{array}{l}\text { P. polonica } \\
\text { (JX276065) }\end{array}$ & 12 & $9.2 \pm 0.25$ & $103.6 \pm 3.57$ & $11(4)$ & 2 & 0 & 100 \\
\hline & $\begin{array}{l}\text { P. polonica } \\
\text { (KF234760) }\end{array}$ & 12 & $10.3 \pm 0.54$ & $104.4 \pm 6.45$ & $10(0)$ & 0 & 0 & 91.67 \\
\hline & $\begin{array}{l}\text { P. } \times \text { cambivora } \\
(\mathrm{J} X 276088)\end{array}$ & 12 & $10.5 \pm 0.53$ & $104.2 \pm 7.28$ & $8(0)$ & 2 & 0 & 83.3 \\
\hline
\end{tabular}

\subsection{Statistical Analyses}

Based on the length and width, the surface of each necrosis was calculated using the mathematical formula for elliptic surfaces. For each treatment, means $\left(x^{-}\right)$and standard errors $( \pm \mathrm{SE})$ of necrosis length, width, and surface were calculated. Analysis of variance was performed using a Generalized Linear Model (GLM), with a significance level of $\alpha=0.05$. Testing of significance of differences in mean necrosis length, width, and surface between different treatments was performed using Tukey's HSD post hoc test $(\alpha=0.05)$. Statistical procedures were performed with the RStudio software version 1.1.383 (Integrated Development for R. RStudio, Inc., Boston, MA, USA).

\section{Results}

\subsection{Phytophthora Species in Poplar Plantations}

In total, 45 isolates of six different Phytophthora species were isolated from 24 of 28 soil samples $(86 \%)$ (Table 1). The most common was P. plurivora (15 samples $=53.6 \%)$, followed by Phytophthora pini Leonian $(7$ samples $=25 \%)$, Phytophthora gonapodyides (H.E. Petersen) Buisman $(6$ samples $=21.4 \%)$, and P. polonica, Phytophthora lacustris Nechwatal et al. and P. cactorum (each 4 samples $=14.3 \%$ ) (Table 1$)$. In the mainly healthy stands 1 and 3, all samples were taken underneath non-symptomatic trees. Additionally, in stand 2, five of the six samples originated from non-symptomatic trees. In contrast, six of the seven samples in stand 4 were taken from trees with high crown transparency and yellowing of leaves. In the rhizosphere of each four declining trees, P. plurivora and P. polonica were found (Table 1). The three samples taken in stands 5 and 6 originated from trees showing severe dieback. Phytophthora gonapodyides was isolated from all three samples, while P. plurivora was present in one sample (Table 1). Co-occurrence of two different Phytophthora species was found in 11 of the 25 samples, while in one sample, three Phytophthora spp. co-occurred (Table 1).

The morphology of all isolates of P. cactorum, P. pini, P. plurivora, and P. polonica conformed with the original descriptions [2,18-21]. In accordance with [22], P. lacustris and P. gonapodyides did not form gametangia in pure cultures or in the mating tests. This is the first report of P. lacustris, P. gonapodyides, P. pini, and P. polonica on poplars in Serbia. 


\subsection{Soil Infestation Test}

Five weeks after the inoculation (pi), the first symptoms like slight yellowing and atrophy of leaves were noticed in clone I-214 in the substrate infested by P. plurivora. Eight weeks pi, the first dieback of plants occurred in both clones in the substrate infested by P. plurivora, P. pini, and P. gonapodyides. Ten weeks pi, dieback also started in clone I-214 infested by P. cactorum and in clone Pánnonia in the substrate infested by the P. polonica strain originally isolated from oak. These diebacks were followed by premature shedding of leaves and total plant collapse. In addition, in the treatment Pánnonia/P. plurivora (KF234737), collar necroses were observed on two plants (Figure 2o). Ten weeks pi and after three flooding periods, numerous plants started to decline in most of the treatments (Table 2), and the experiment was assessed.
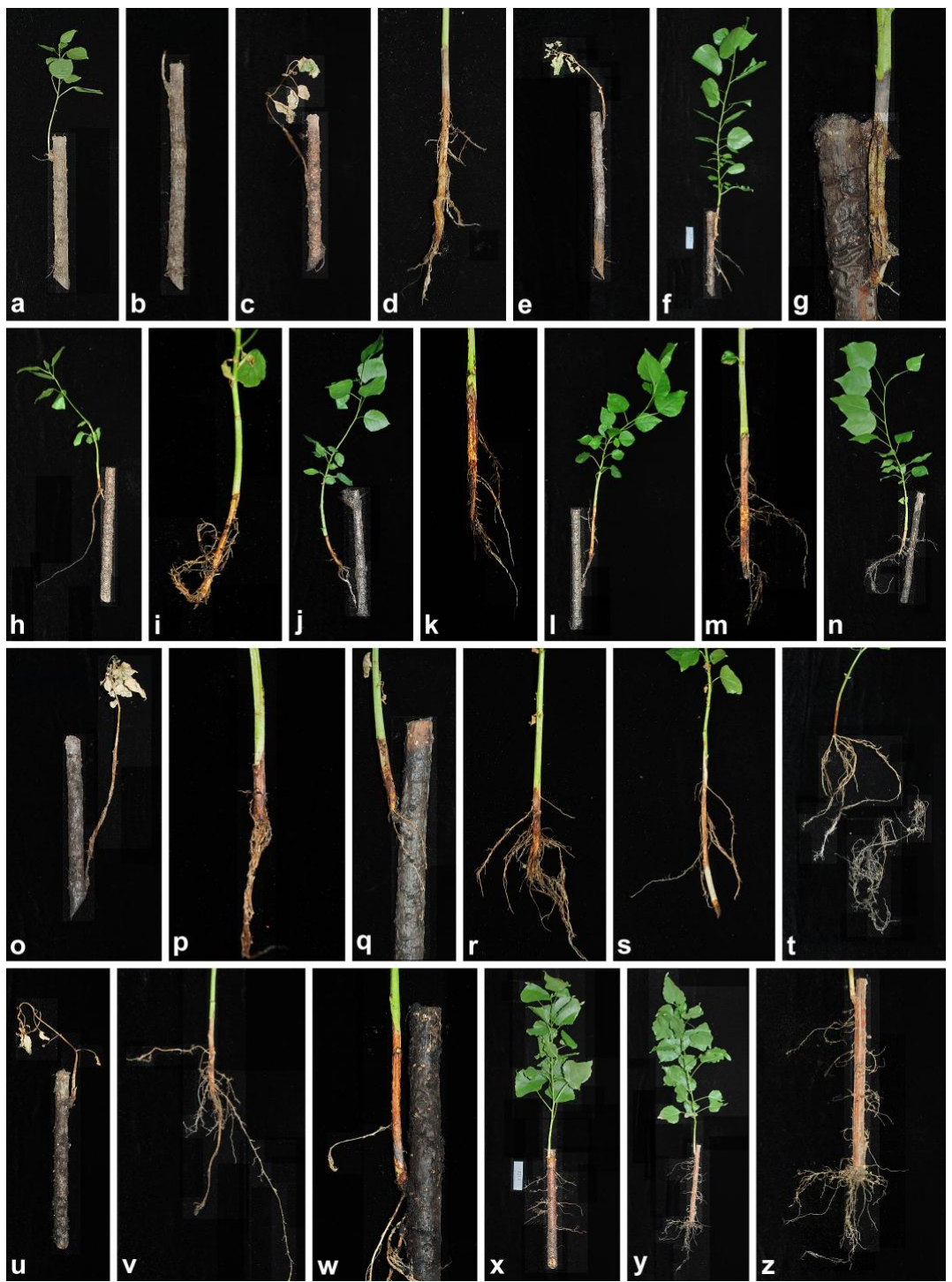

Figure 2. Representative cuttings of poplar clone I-214 after ten weeks in soil infested with nine Phytophthora spp.: (a,b) P. cactorum; (c,d) P. cryptogea; (e) P. gonapodyides; (f,g) P. lacustris; (h,i) P. pini KF234655; (j,k) P. pini KF234658; (1,m) P. plurivora KF234737; (n,o) P. plurivora KF234740; (p,q) P. polonica JX276065; $(\mathbf{r}, \mathbf{s})$ P. polonica KF234760; (t,u) P. $\times$ serendipita; $(\mathbf{v}, \mathbf{w})$ P. $\times$ cambivora; $(\mathbf{x}, \mathbf{z})$ control.

The most aggressive species to poplar clone I-214 were $P$. plurivora (KF234740) and $P$. $\times$ serendipita, each causing the decline of 11 poplar plants (91.67\%), followed by both strains of P. pini (10 declining 
plants $=83.3 \%$ ) (Table 2). In several treatments, necrotic bark lesions were recorded (Figure 2). Most Phytophthora species caused root rot and the loss of fine roots (Figure 2). The reduction of total root dry weight compared to the control was most severe for the two isolates of P. plurivora (30.4\% and $35.1 \%$, respectively) and the two isolates of P. pini (31.8\% and 32.2\%, respectively). Both pathogens caused $100 \%$ root rot in $75-91.2 \%$ of plants (Table 2). In the case of clone Pánnonia, the most aggressive species were $P$. gonapodyides and one isolate of $P$. pini (KF234658), which both caused 100\% mortality, followed by P. cactorum, P. $\times$ cambivora and P. polonica each killing 10 plants (83.3\%) (Table 2). Root rot and loss of fine roots were recorded in all treatments (Figure 2). The highest reduction of total root dry weight was caused by P. gonapodyides (25.4\% compared to the control) and one isolate of P. pini (26.8\%) (Table 2). These two species also killed all plants (Table 2). Additionally, all other Phytophthora species/isolates caused severe reductions of total root dry weight (28.2-40.5\% compared to the control) and $100 \%$ root rot in 33.3-91.7\% of plants (Table 2). In addition, several Phytophthora species caused girdling and longitudinal bark lesions (Figure 3).
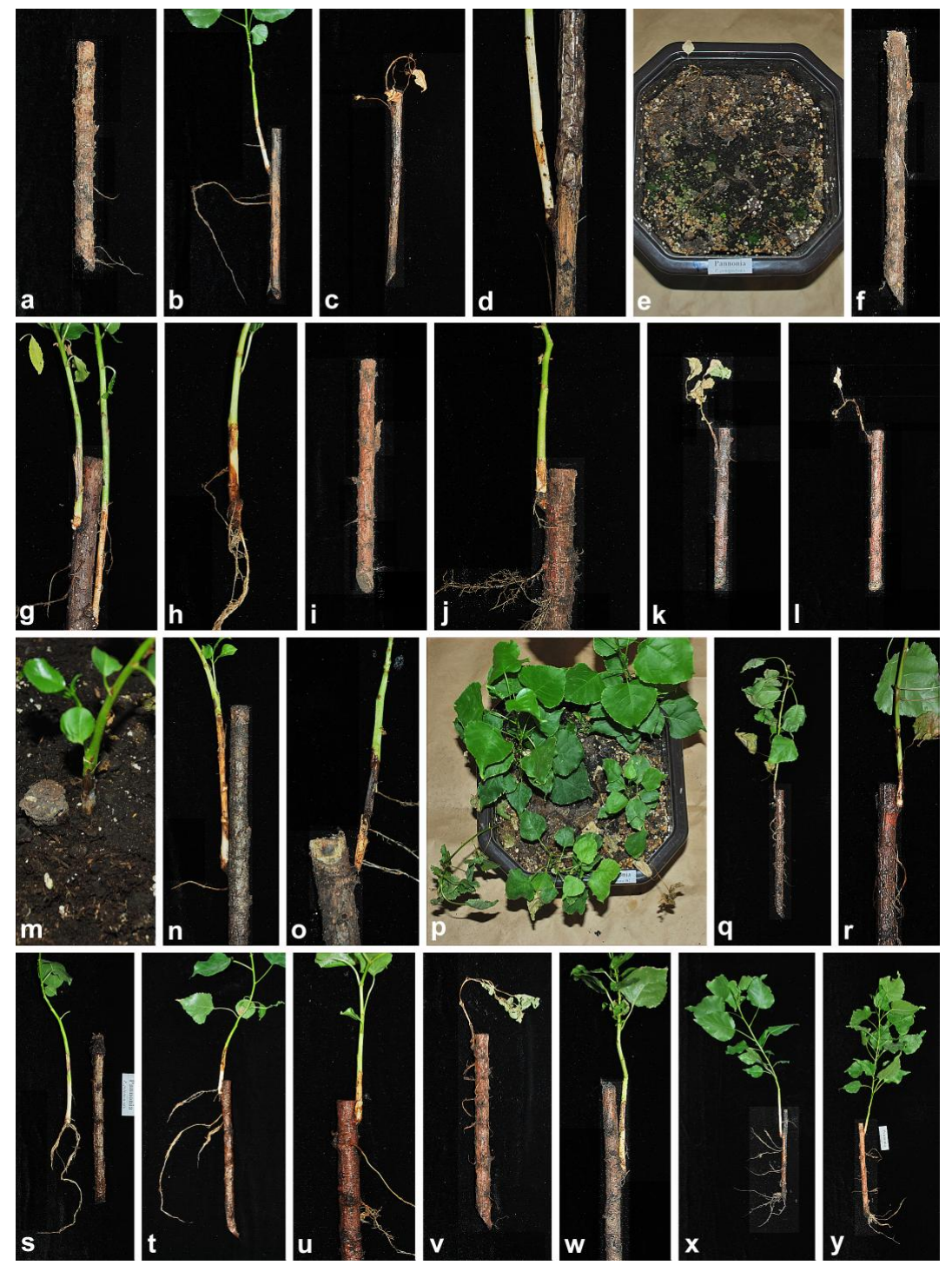

Figure 3. Representative cuttings of poplar clone Pánnonia after ten weeks in soil infested with nine Phytophthora spp.: (a,b) P. cactorum; (c,d) P. cryptogea; (e,f) P. gonapodyides; (g,h) P. lacustris; (i,j) P. pini KF234655; (k,l) P. pini KF234658; (m,o) P. plurivora KF234737; (p,r) P. plurivora KF234740; (s) P. polonica JX276065; (t) P. polonica KF234760; (u,v) P. × cambivora; (w) P. $\times$ serendipita; $(\mathbf{x}, \mathbf{y})$ control. 


\subsection{Underbark Inoculation Test}

Recorded symptoms and numbers of plants with dieback are shown in Table 3 and Figures 4 and 5 . Four weeks after inoculation (pi), the first discrete bark necroses were observed, soon followed by the oozing of exudates. In clone I-214, these symptoms appeared first in the treatments with both $P$. pini isolates and one isolate of P. plurivora (KF234737). In clone Pánnonia, the first bleeding lesions were caused by $P$. cactorum. Six weeks pi, intensive bleeding lesions on both clones were recorded in the treatments with P. pini, P. plurivora, and P. cactorum. In addition, in clone I-214, small necroses were caused by $P$. lacustris, while in clone Pánnonia, bleeding cankers started to appear on individual plants infected by P. lacustris, P. gonapodyides, and the P. polonica isolate from oak (JX276065). Eight weeks pi, symptoms had progressed and numerous secondary shoots started to develop at the margins of necrotic zones (Figure 5b,c). In addition, the first plants with dieback were observed in the I-214/P. pini (KF234655) and the Pánnonia/P. gonapodyides treatments. Eleven weeks pi, more plants of both clones showed dieback and other symptoms, and the experiment was finished. Reisolations were successful in all treatments except of the controls, although with slightly lower reisolation rates in some cases (Table 3).

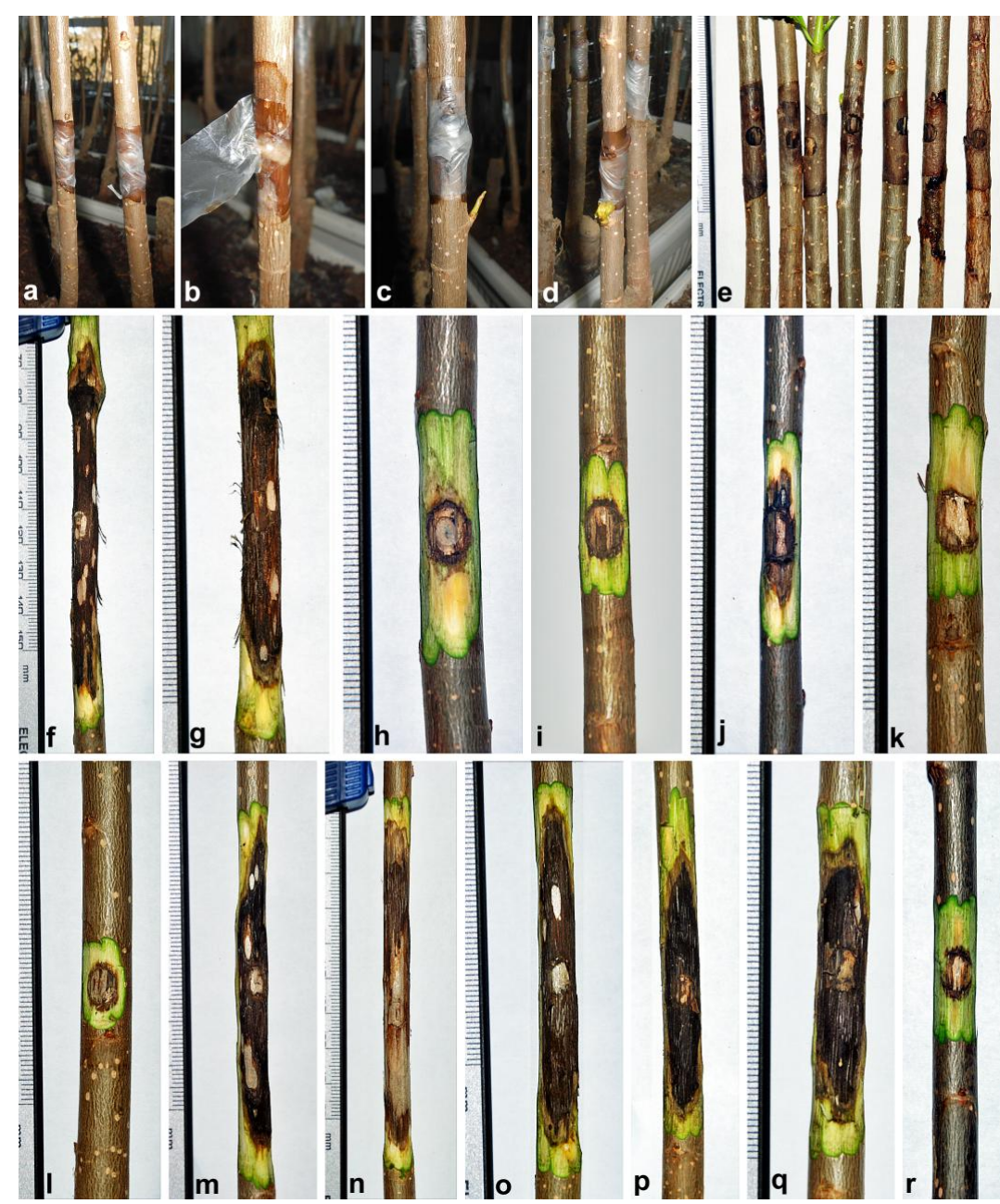

Figure 4. Representative symptoms caused by seven Phytophthora spp. on cuttings of poplar clone I-214 in the underbark inoculation test: $(\mathbf{a}, \mathbf{d})$ bleeding bark lesions after eight weeks: $(\mathbf{a}, \mathbf{b})$ P. pini; (c) P. cactorum, with beginning formation of secondary shoot; (d) P. plurivora, with beginning formation of secondary shoot; (e) cuttings inoculated with P. pini (KF234655) after 11 weeks; (f,r) necrotic lesions of the inner bark after 11 weeks: (f,g) P. cactorum; (h) P. $\times$ cambivora; (i) P. gonapodyides; (j) P. lacustris; (k) P. polonica JX276065; (1) P. polonica KF234760; (m) P. pini KF234658; (n) P. pini KF234655; (o,p) P. plurivora KF234740; (q) P. plurivora KF234737; (r) control. 


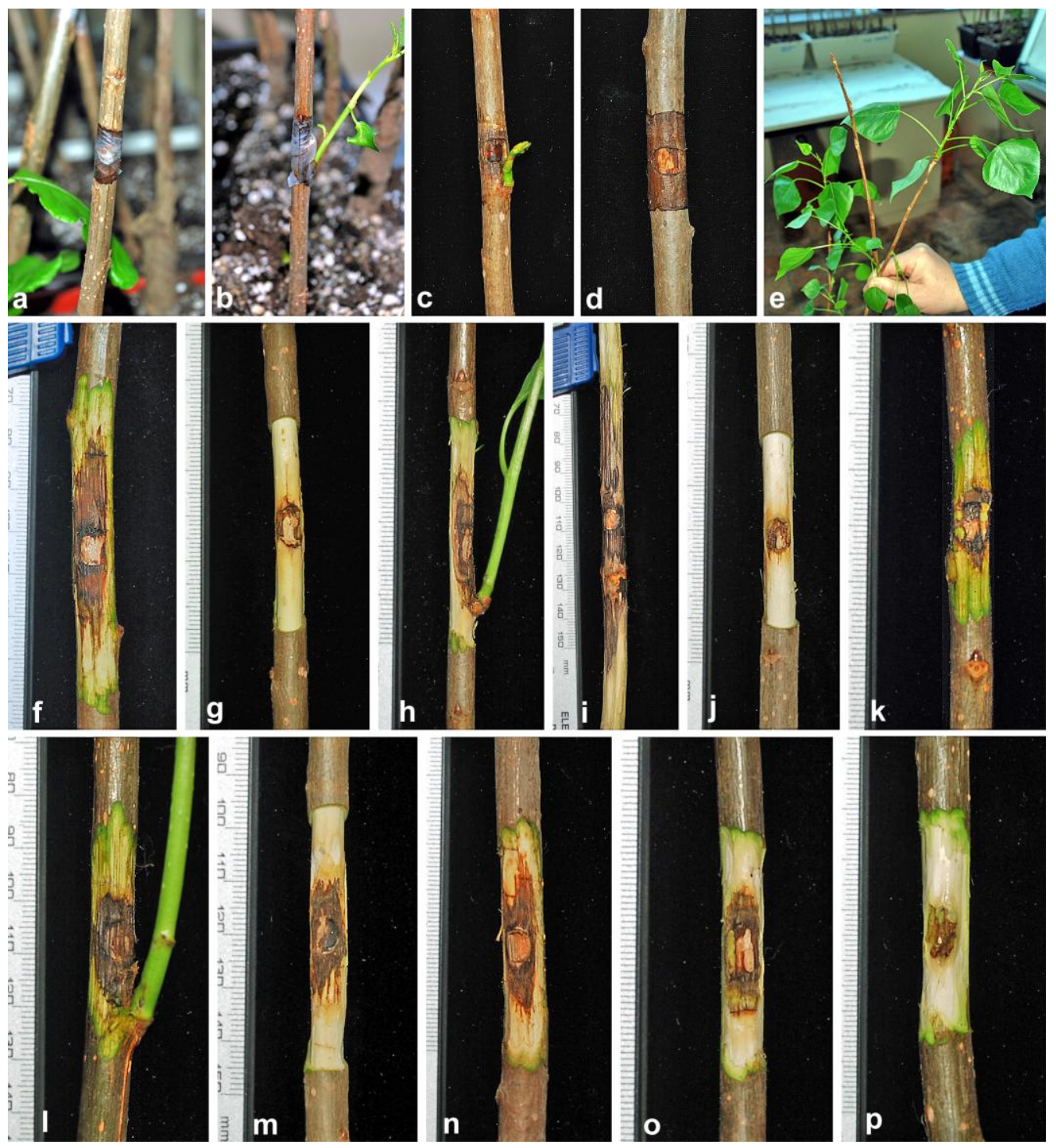

Figure 5. Representative symptoms caused by seven Phytophthora spp. on cuttings of poplar clone Pánnonia in the underbark inoculation test: $(\mathbf{a}, \mathbf{b})$ bleeding bark lesions after eight weeks: (a) P. cactorum; (b) P. lacustris, with formation of secondary shoot. (c,d) necrotic lesions of outer bark after 11 weeks: (c) $P$. plurivora, with beginning formation of secondary shoot; (d) P. gonapodyides. (e) declining and healthy plants inoculated with P. pini after eight weeks. (f-p) necrotic lesions of the inner bark after 11 weeks: (f) P. cactorum; (g) P. $\times$ cambivora; (h) P. lacustris; (i) P. gonapodyides; (j) P. polonica JX276065; (k) P. polonica KF234760; (1) P. pini KF234658; (m) P. pini KF234655; (n) P. plurivora KF234737; (o) P. plurivora KF234740; (p) control.

The statistical analyses showed that in clone I214, most Phytophthora species significantly influenced most of the tested parameters. Exceptions were found for P. gonapodyides and P. polonica and lesion lengths; P. gonapodyides, P. lacustris, P. polonica and P. $\times$ cambivora and lesion widths; and P. gonapodyides, P. lacustris, and P. polonica and the surface areas of the lesions (Table 4). In the case of clone Pánnonia, only in plants infected with P. polonica (JX276065) and P. $\times$ cambivora did the lesion lengths differ significantly from the control. In contrast, plants infected with P. gonapodyides, P. pini (KF234655), and P. polonica (KF234760) showed significantly higher lesion widths compared to the control plants (Table 4). Lesions caused by these three Phytophthora spp. and P. cactorum also showed 
significantly higher surface areas compared to the control (Table 4). Results of Tukey's test are shown in Table 5.

Table 4. Estimates, $t$ values, $p$ values, and Residual deviances from GLM for tested parameters in the underbark inoculation trial with poplars. In clone I-214, degrees of freedom (df) for Residual deviance was 114; in clone Pánnonia df for Residual, deviance was 109. Significant effects are marked in bold type.

\begin{tabular}{|c|c|c|c|c|c|c|c|c|c|c|}
\hline \multirow{2}{*}{$\begin{array}{c}\text { Poplar } \\
\text { Clone Host }\end{array}$} & \multirow{2}{*}{ Treatment } & \multicolumn{3}{|c|}{ Length } & \multicolumn{3}{|c|}{ Width } & \multicolumn{3}{|c|}{ Surface } \\
\hline & & Estimate & $t$ Value & $(p)$ & Estimate & $t$ Value & $(p)$ & Estimate & $t$ Value & $(p)$ \\
\hline \multirow{12}{*}{ I 214} & Control & 2.32 & 19.44 & 0.000 & 1.95 & 33.29 & 0.000 & 4.03 & 21.78 & 0.000 \\
\hline & P. cactorum & 1.66 & 10.04 & 0.000 & 0.63 & 7.70 & 0.000 & 2.35 & 9.17 & 0.000 \\
\hline & P. gonapodyides & 0.11 & 0.67 & 0.506 & -0.07 & -0.84 & 0.405 & 0.05 & 0.18 & 0.855 \\
\hline & P. lacustris & 0.45 & 2.71 & 0.008 & 0.01 & 0.14 & 0.890 & 0.49 & 1.92 & 0.057 \\
\hline & $\begin{array}{c}\text { P. pini } \\
\text { (KF234655) }\end{array}$ & 1.72 & 9.96 & 0.000 & 0.67 & 7.91 & 0.000 & 2.47 & 9.21 & 0.000 \\
\hline & $\begin{array}{c}\text { P.pini } \\
\text { (KF234658) }\end{array}$ & 1.46 & 8.65 & 0.000 & 0.56 & 6.69 & 0.000 & 2.05 & 7.82 & 0.000 \\
\hline & $\begin{array}{l}\text { P. plurivora } \\
\text { (KF234737) }\end{array}$ & 0.89 & 5.24 & 0.000 & 0.32 & 3.89 & 0.000 & 1.25 & 4.78 & 0.000 \\
\hline & $\begin{array}{l}\text { P. plurivora } \\
\text { (KF234740) }\end{array}$ & 1.45 & 8.59 & 0.000 & 0.57 & 6.98 & 0.000 & 2.0 & 7.62 & 0.000 \\
\hline & $\begin{array}{l}\text { P. polonica } \\
\text { (JX276065) }\end{array}$ & -0.03 & -0.18 & 0.861 & 0.01 & 0.07 & 0.947 & -0.02 & -0.09 & 0.933 \\
\hline & $\begin{array}{c}\text { P. polonica } \\
\text { (KF234760) }\end{array}$ & -0.02 & -0.12 & 0.909 & -0.08 & -0.99 & 0.323 & -0.1 & -0.38 & 0.703 \\
\hline & P. $\times$ cambivora & 0.50 & 2.96 & $<0.010$ & -0.05 & -0.56 & 0.579 & 0.66 & 2.53 & 0.013 \\
\hline & $\begin{array}{l}\text { Residual } \\
\text { deviance }\end{array}$ & & 12.4 & & & 4.05 & & & 27.33 & \\
\hline \multirow{12}{*}{ Pánnonia } & Control & 2.29 & 14.83 & 0.000 & 1.99 & 22.85 & 0.000 & 4.05 & 15.02 & 0.000 \\
\hline & P. cactorum & 1.07 & 4.76 & 0.000 & 0.19 & 1.48 & 0.141 & 1.32 & 3.38 & $<0.010$ \\
\hline & P. gonapodyides & 1.11 & 3.89 & 0.000 & 0.56 & 3.45 & $<0.010$ & 2.16 & 4.33 & 0.000 \\
\hline & P. lacustris & 0.57 & 2.62 & $<0.010$ & 0.02 & 0.16 & 0.870 & 0.64 & 1.68 & 0.096 \\
\hline & $\begin{array}{c}\text { P.pini } \\
\text { (KF234655) }\end{array}$ & 1.03 & 4.61 & 0.000 & 0.48 & 3.81 & 0.000 & 1.72 & 4.41 & 0.000 \\
\hline & $\begin{array}{c}\text { P. pini } \\
\text { (KF234658) }\end{array}$ & 0.53 & 2.36 & 0.020 & 0.14 & 1.11 & 0.270 & 0.68 & 1.73 & 0.086 \\
\hline & $\begin{array}{l}\text { P. plurivora } \\
\text { (KF234737) }\end{array}$ & 0.55 & 2.51 & 0.014 & 0.16 & 1.26 & 0.212 & 0.72 & 1.88 & 0.063 \\
\hline & $\begin{array}{l}\text { P. plurivora } \\
\text { (KF234740) }\end{array}$ & 0.64 & 2.85 & $<0.010$ & 0.16 & -0.43 & 0.210 & 0.79 & -0.02 & 0.045 \\
\hline & $\begin{array}{l}\text { P. polonica } \\
\text { (JX276065) }\end{array}$ & 0.05 & 0.22 & 0.826 & -0.05 & 2.66 & 0.670 & -0.01 & 2.95 & 0.982 \\
\hline & $\begin{array}{l}\text { P. polonica } \\
\text { (KF234760) }\end{array}$ & 0.50 & 2.26 & 0.026 & 0.33 & 1.18 & $<0.010$ & 1.12 & 1.61 & $<0.010$ \\
\hline & P. $\times$ cambivora & 0.26 & 1.20 & 0.232 & 0.15 & 1.26 & 0.241 & 0.61 & 2.02 & 0.111 \\
\hline & $\begin{array}{l}\text { Residual } \\
\text { deviance }\end{array}$ & & 20.89 & & & 7.36 & & & 53.52 & \\
\hline
\end{tabular}

The two isolates of P. pini were most aggressive to clone I-214, causing bleeding lesions in 66.7 and $91.3 \%$ of plants and dieback in $8.3 \%$ and $41.7 \%$ of plants, respectively (Table 3 ). Also, P. cactorum (bleeding lesions in $75 \%$ of plants) and the two isolates of $P$. plurivora (bleeding lesions in $50 \%$ and $75 \%$ of plants, respectively) showed considerable aggressiveness to clone I-214 (Table 3). These three Phytophthora species also caused the largest bark lesions with mean necrosis areas that were statistically significantly different from all other treatments and the control, ranging between $415.5 \pm 60.2$ and 668.1 $\pm 128.1 \mathrm{~mm}^{2}$ (Table 5). Phytophthora gonapodyides and both isolates of P. polonica were non-pathogenic to the bark of clone I-214, while $P . \times$ cambivora was mildly pathogenic (Tables 3 and 5). 
Table 5. Mean values, standard errors, and results of Tukey's post hoc tests for the bark necroses caused by seven Phytophthora spp. in the underbark inoculation test on poplar clones I-214 and Pánnonia after 11 weeks. Different letters behind values indicate significant differences $(\alpha=0.05)$.

\begin{tabular}{|c|c|c|c|c|c|c|}
\hline \multirow{2}{*}{$\begin{array}{c}\text { Phytophthora } \\
\text { Species } \\
\text { (Isolates) }\end{array}$} & \multicolumn{3}{|c|}{ Poplar Clone I-214 (Mean \pm SE+Tukey's Test) } & \multicolumn{3}{|c|}{ Poplar Clone Pánnonia (Mean \pm SE+Tukey's Test) } \\
\hline & $\begin{array}{c}\text { Necrosis } \\
\text { Length }(\mathrm{mm})\end{array}$ & $\begin{array}{l}\text { Necrosis Width } \\
(\mathrm{mm})\end{array}$ & $\begin{array}{l}\text { Necrosis Area } \\
\left(\mathrm{mm}^{2}\right)\end{array}$ & $\begin{array}{c}\text { Necrosis } \\
\text { Length }(\mathrm{mm})\end{array}$ & $\begin{array}{l}\text { Necrosis Width } \\
\quad(\mathrm{mm})\end{array}$ & $\begin{array}{l}\text { Necrosis Area } \\
\left(\mathrm{mm}^{2}\right)\end{array}$ \\
\hline Control & $10.2 \pm 0.18 \mathrm{f}$ & $7 \pm 0.18 \mathrm{~F}$ & $56.5 \pm 1.87 \mathrm{f}$ & $9.9 \pm 0.38 \mathrm{~d}$ & $7.3 \pm 0.19 \mathrm{c}$ & $57.5 \pm 3.30 \mathrm{~d}$ \\
\hline P. cactorum & $53.7 \pm 5.61 \mathrm{abcd}$ & $13.2 \pm 1.13 \mathrm{abcd}$ & $592.9 \pm 104.52 \mathrm{abcd}$ & $28.8 \pm 5.14 \mathrm{abc}$ & $8.9 \pm 0.42 \mathrm{abc}$ & $214.9 \pm 47.02 \mathrm{abcd}$ \\
\hline P. gonapodyides & $11.4 \pm 0.61 \mathrm{f}$ & $6.6 \pm 0.14 \mathrm{f}$ & $59.2 \pm 3.88 \mathrm{f}$ & $30 \pm 17.43^{\mathrm{a} a b c}$ & $12.8 \pm 3.61^{\mathrm{a} a b c}$ & $\begin{array}{c}496.4 \pm 404.56 \\
\text { a abcd }\end{array}$ \\
\hline P. lacustris & $16 \pm 1.69 \mathrm{ef}$ & $7.1 \pm 0.29 \mathrm{f}$ & $92.4 \pm 13.19$ ef & $17.6 \pm 1.54 \mathrm{abcd}$ & $7.5 \pm 0.46 c$ & $109.3 \pm 16.97 \mathrm{abcd}$ \\
\hline $\begin{array}{c}\text { P. pini } \\
\text { (KF234655) }\end{array}$ & $57.2 \pm 6.39 \mathrm{abcd}$ & $13.8 \pm 1.12 \mathrm{abcd}$ & $668.8 \pm 128.10 \mathrm{abcd}$ & $27.8 \pm 6.24 a b c$ & $11.9 \pm 1.50 \mathrm{abc}$ & $321.5 \pm 118.21 \mathrm{abcd}$ \\
\hline $\begin{array}{c}\text { P. pini } \\
\text { (KF234658) }\end{array}$ & $44 \pm 3.69 \mathrm{abcd}$ & $12.3 \pm 0.52 \mathrm{abcde}$ & $437.1 \pm 59.78 \mathrm{abcd}$ & $16.8 \pm 0.96 \mathrm{abcd}$ & $8.4 \pm 0.54 \mathrm{cbc}$ & $113.2 \pm 11.83 \mathrm{abcd}$ \\
\hline $\begin{array}{l}\text { P. plurivora } \\
\text { (KF234737) }\end{array}$ & $24.7 \pm 2.93 \mathrm{ef}$ & $9.7 \pm 0.46 \mathrm{cde}$ & $197.2 \pm 33.26 \mathrm{cdef}$ & $17.2 \pm 0.70 \mathrm{abd}$ & $8.6 \pm 0.40 \mathrm{cbc}$ & $117.7 \pm 10.72 \mathrm{abcd}$ \\
\hline $\begin{array}{l}\text { P. plurivora } \\
\text { (KF234740) }\end{array}$ & $43.5 \pm 4.76 \mathrm{abcd}$ & $11.6 \pm 0.72 \mathrm{abcde}$ & $415.5 \pm 60.22$ abcde & $18.8 \pm 1.27 \mathrm{abcd}$ & $8.6 \pm 0.38 \mathrm{cbc}$ & $126.8 \pm 6.29 \mathrm{abcd}$ \\
\hline $\begin{array}{l}\text { P. polonica } \\
\text { (JX276065) }\end{array}$ & $9.9 \pm 0.25 f$ & $7.1 \pm 0.22 \mathrm{f}$ & $55.3 \pm 2.57 f$ & $10.4 \pm 0.41 d$ & $7 \pm 0.15 c$ & $57 \pm 2.67 d$ \\
\hline $\begin{array}{l}\text { P. polonica } \\
\text { (KF234760) }\end{array}$ & $10 \pm 0.24 \mathrm{f}$ & $6.5 \pm 0.20 \mathrm{f}$ & $51.2 \pm 2.22 f$ & $16.3 \pm 4.35 \mathrm{abcd}$ & $10.2 \pm 1.31 \mathrm{cbc}$ & $177 \pm 93.63 \mathrm{abcd}$ \\
\hline P. $\times$ cambivora & $16.8 \pm 4.99 \mathrm{ef}$ & $6.7 \pm 0.59 \mathrm{f}$ & $109.4 \pm 51.31 \mathrm{ef}$ & $12.9 \pm 2.14 \mathrm{ad}$ & $8.5 \pm 1.20 \mathrm{cbc}$ & $106.2 \pm 39.73 \mathrm{abcd}$ \\
\hline
\end{tabular}

${ }^{a}$ Due to the mortality of seven plants only five plants had clearly visible necroses margins which were measured.

In contrast, on clone Pánnonia, P. gonapodyides was by far the most aggressive species, causing the dieback of $58.3 \%$ of plants and the largest bark lesions with a mean necrosis area of $496.37 \pm 404.56$ $\mathrm{mm}^{2}$, followed by P. cactorum with dieback in $16.7 \%$ of plants and P. pini and P. plurivora each causing dieback in $8.3 \%$ of plants (Table 3). All Phytophthora species and isolates, except of the P. polonica isolate from oak (JX276065), caused bleeding bark lesions with sizes significantly different from the control (Figure 5; Table 5).

\section{Discussion}

Prior to this study, very little was known about the occurrence and role of Phytophthora species in poplar stands. Phytophthora cactorum had been isolated from bleeding cankers of Populus alba in the Czech Republic [11] and from the rhizosphere of young P. alba trees in Hungary [4], while $P$. $\times$ cambivora was recovered from poplar trees in Croatia [12]. A preliminary study demonstrated the presence of P. cactorum and P. plurivora in the rhizosphere of poplar trees in Serbia [13].

In the present work, a community of six Phytophthora species, P. cactorum, P. gonapodyides, P. lacustris, P. pini, P. plurivora and P. polonica, was found in the rhizosphere of $85 \%$ of sampled trees in six riparian poplar plantations in Serbia. While P. gonapodyides and P. lacustris might be native to Europe, the other four Phytophthora species are considered as introduced invasive pathogens in Europe [3-5,20]. The known host-Phytophthora associations of P. cactorum and P. plurivora and Populus spp. [4,11-13] were confirmed by this study. In both the soil infestation and the underbark inoculation test, $P$. cactorum and P. plurivora demonstrated high aggressiveness to the roots and bark of poplar clones I-214 and Pánnonia. In addition, this study also extended the knowledge on the distribution and host ranges of several Phytophthora species with P. gonapodyides, P. lacustris, P. pini, and P. polonica being the first records from poplar trees, and the latter two Phytophthora species also being the first records from Serbia and the Balkan region in general.

Phytophthora pini, like P. plurivora, belongs to the 'P. citricola complex' within Phytophthora phylogenetic Clade $2[21,25]$. It was previously recorded on at least seven different plant species in North America and Europe, mainly ornamentals, but also Pinus resinosa Ait. and mature F. sylvatica trees $[4,5,21,26-29]$. However, its host range is most likely considerably wider since many plant 
diseases assigned in the past to P. citricola s.l. Sawada were most likely caused by P. plurivora and P. pini [20,21]. Phytophthora pini also occurs in water courses and irrigation reservoirs in North America [21]. The findings of this species in riparian poplar stands along the Sava River in Serbia are in accordance with its preference of wet sites. Like P. plurivora, in both the soil infestation and the underbark inoculation test, $P$. pini was highly aggressive to both tested poplar cultivars, and in particular to clone I-214. This is of high concern since I-214 is one of the most common clones used in poplar plantations in Serbia. Due to their high aggressiveness to poplars and other tree species, their wide host ranges, and homothallic production of oospores, acting as enduring survival structures $[3,5,20,21]$, the presence of $P$. pini and P. plurivora most likely poses a serious risk to planted and natural stands of poplars and other tree species in Serbia.

Phytophthora polonica from Clade 9 [30] is also homothallic and was originally described from the rhizosphere of declining Alnus glutinosa (L.) Gaertn. trees in Poland [19]. Recently, this species was isolated from soils of declining Juglans nigra L. and Q. robur stands in Hungary and Poland [31,32], respectively. Furthermore, in Serbia, P. polonica was previously isolated in 2011 from declining Q. robur trees [33]. In previous pathogenicity tests, P. polonica proved only weakly pathogenic to Alnus shoots and was non-pathogenic to shoots of Fraxinus angustifolia Vahl and three Quercus spp. [19]. In the present study, P. polonica was isolated from the rhizosphere of symptomatic poplar trees and caused significant root rot, extensive loss of fine roots, and dieback on poplar clones I-214 and Pánnonia in the soil infestation test. In contrast, this pathogen was almost non-pathogenic to poplar bark in the underbark inoculation test. These results suggest the involvement of $P$. polonica in the complex of poplar dieback as a serious fine root pathogen which is not progressing into the suberised roots. In previous studies, a similar aetiology was demonstrated for P. quercina Jung and European oak decline [14,16,34-36].

Interestingly, in both pathogenicity tests, P. gonapodyides from Clade 6 [30] was the most aggressive species to clone Pánnonia, causing extensive root rot, fine root loss, bark lesions, and dieback. Phytphthora gonapodyides is considered as an opportunistic pathogen with a mainly aquatic lifestyle [37,38]. However, P. gonapodyides is also involved in the declines of oak and beech stands on mesic sites in Germany and the decline of Quercus ilex L. in xeric conditions in Spain [3,14-16,39]. Due to its ubiquitous presence in watercourses across Europe and its high aggressiveness to clones Pánnonia and I-214, this pathogen poses a significant threat to riparian poplar stands. Phytophthora lacustris is another Clade 6 species [30] commonly occurring in waterways and in riparian stands [22]. In the soil infestation test, P. lacustris caused extensive fine root damage, girdling and longitudinal bark lesions developing from the infected root system into the stem, and dieback on both poplar clones. In contrast, in the underbark inoculation trial, this species was only slightly pathogenic to both clones, indicating flooding as an indispensable requisite for successful infections in this aquatic Phytophthora species. As with P. gonapodyides, the ubiquitous presence of P. lacustris in European waterways might pose a risk to the health of riparian poplar stands in Serbia and elsewhere. Phytophthora cactorum, P. lacustris (referred to as $P$. taxon salixsoil Brasier et al.), and P. plurivora also proved to be pathogenic to the roots and bark of Fraxinus excelsior, another common species in riparian forest stands [40].

It is possible that the six isolated Phytophthora species were already present at the sites before the six poplar plantations sampled in this study were established. River water appears as the most likely natural pathway of introduction since all six plantations are located in the flood plains of the Sava River, experiencing in most years strong floodings [41], or smaller rivers in central Serbia, respectively. On a global scale, river water is ubiquitously infested with a wide array of Phytophthora species [37,42-49]. The importance of water as a source of Phytophthora inoculum was convincingly demonstrated by several studies [50-56]. Severe and long-during floodings such as those affecting wide regions of Serbia in the years 2014 and 2016 are, hence, of particular concern as they enable the spread of a diverse range of harmful Phytophthora species from large catchments to forests and plantations situated in the floodplains downstream. However, against the background of almost ubiquitous infestations of nursery stands in Europe with a total of more than 50 Phytophthora species [4,7,57], including 
P. cactorum, P. gonapodyides, P. lacustris, P. pini, P. plurivora, and P. polonica, a possible introduction of these Phytophthora species to the Serbian poplar plantations with infested nursery stock cannot be ruled out. Unfortunately, it was not possible to identify and sample the nurseries from where the plants, used for the establishment of the Phytophthora-infested poplar plantations in Serbia, originated.

In conclusion, the presence of the six Phytophthora species in the sampled poplar stands poses a serious threat to poplars, in particular to plants in young plantations, and potentially also to other riparian tree species. Continued monitoring of the presence and diversity of Phytophthora species in riparian poplar stands and other hygrophilic stands and in water courses in Serbia is urgently required in order to assess the magnitude of the problem and develop appropriate management concepts for the disease. Since the riparian poplar plantations are seasonally flooded with Phytophthora-infested river water, the repeated introduction and spread of Phytophthora spp. into and within the poplar plantations cannot be prevented. Direct control of Phytophthora spp. with fungizides like metalaxyl is impossible since their application is not permitted in riparian stands. Furthermore, the use of potassium phosphite, which is globally the most efficient control measure for forest Phytophthora diseases $[5,58]$, is no longer possible due to its recent registration as a fungizide in Europe. Therefore, the most promising management measure will be the use of less susceptible poplar clones or other less susceptible riparian tree species, which requires extensive host range testing with the six Phytophthora species and other poplar clones and riparian tree species.

\section{Conclusions}

(1) A community of six different Phytophthora species, P. cactorum, P. gonapodyides, P. lacustris, P. pini, $P$, plurivora, and P. polonica, was detected in each of the three symptomatic and healthy, riparian poplar plantations in Serbia.

(2) In both a soil infestation test and an underbark inoculation test, all six Phytophthora species proved their pathogenicity to four-month and one-year-old cuttings of poplar clones I-214 and Pánnonia, respectively.

(3) The results suggest the involvement of soilborne Phytophthora species as fine root and bark pathogens in the decline of poplar plantations. The presence of these Phytophthora species in riparian poplar plantations might also pose a serious risk to other riparian forest communities, in particular the natural stands of Quercus robur and Fraxinus angustifolia.

Author Contributions: Conceptualization, I.M. and T.J.; Funding acquisition, T.O.; Methodology, I.M., N.K., D.K., Z.R., J.A.N., K.S., T.C. and T.J.; Writing-original draft, I.M., N.K., and T.J.

Funding: This research was funded by: Ministry of Education, Science and Technological Development, Republic of Serbia, grant number TR 37008; European Union's Horizon 2020 research and innovation programme under grant agreement-“Pest Organisms Threatening Europe-POnTE" Project ID: 635646; "Phytophthora Research Centre", funded by the Czech Ministry for Education, Youth and Sports and the European Regional Development Fund, grant number CZ.02.1.01/0.0/0.0/15_003/0000453;

Acknowledgments: We are grateful to Public Enterprise "Vojvodinašume" for material support during this work. The COST Actions FP0801 and TD1209, as well as Forest Research Institute-IBL Scholarship Grant, are acknowledged for the Short Term Scientific Missions of Ivan Milenković. Malgorzata Borys (IBL, Warsaw, Poland) and Rajka Domuzin (Institute of Forestry, Belgrade, Serbia) are appreciated for their excellent support during the laboratory works. Sanja Ćirić (Jeleč Dekor, Jagodina, Serbia) is acknowledged for providing the poplar cuttings for the pathogenicity tests, and Sabine Werres (JKI, Braunschweig, Germany) for providing the tester strains of P. cryptogea.

Conflicts of Interest: The authors declare no conflict of interest.

\section{References}

1. Beakes, G.W.; Thines, M.; Honda, D. Straminipile "Fungi" - Taxonomy. In Encyclopedia of Life Sciences (eLS); John Wiley and Sons, Ltd.: Chichester, UK, 2015; pp. 1-9.

2. Erwin, D.C.; Ribeiro, O.K. Phytophthora Diseases Worldwide; American Phytopathological Society (APS) Press: St. Paul, MN, USA, 1996; p. 592. ISBN 0-89054-212-0. 
3. Jung, T.; Vettraino, A.M.; Cech, T.; Vannini, A. The impact of invasive Phytophthora species on European forests. In Phytophthora: A Global Perspective; Lamour, K., Ed.; Plant Protection Series 2; CABI: Wallingford, UK, 2013; pp. 146-158. ISBN 978-1-78064-093-8.

4. Jung, T.; Orlikowski, L.; Henricot, B.; Abad-Campos, P.; Aday, A.G.; Aguín Casal, O.; Bakonyi, J.; Cacciola, S.O.; Cech, T.; Chavarriaga, D.; et al. Widespread Phytophthora infestations in European nurseries put forest, semi-natural and horticultural ecosystems at high risk of Phytophthora diseases. For. Pathol. 2016, 46, 134-163. [CrossRef]

5. Jung, T.; Pérez-Sierra, A.; Durán, A.; Horta Jung, M.; Balci, Y.; Scanu, B. Canker and decline diseases caused by soil- and airborne Phytophthora species in forests and woodlands. Persoonia 2018, 40, 182-220. [CrossRef]

6. Brasier, C.M. The biosecurity threat to the UK and global environment from international plant trade. Plant Pathol. 2008, 57, 792-808. [CrossRef]

7. Pérez-Sierra, A.; Jung, T. Phytophthora in woody ornamental nurseries. In Phytophthora: A Global Perspective; Lamour, K., Ed.; Plant Protection Series 2; CABI: Wallingford, UK, 2013; pp. 166-177. ISBN 978-1-78064-093-8.

8. Scott, P.M.; Burgess, T.I.; Hardy, G.E.St.J. Globalization and Phytophthora. In Phytophthora: A Global Perspective; Lamour, K., Ed.; Plant Protection Series 2; CABI: Wallingford, UK, 2013; pp. 226-232. ISBN 978-1-78064-093-8.

9. Keča, L.; Keča, N.; Pantić, D. Net present value and internal rate of return as indicators for assessment of cost-efficiency of poplar plantations: A Serbian case study. Int. For. Rev. 2012, 14, 145-156. [CrossRef]

10. Banković, S.; Medarević, M.; Pantić, D.; Petrović, N.; Šljukić, B.; Obradović, S. The growing stock of the Republic of Serbia-State and problems. Bull. Fac. For. 2009, 100, 7-29, (In Serbian with English summary). [CrossRef]

11. Cerny, K.; Strnadova, V.; Gregorova, B.; Holub, V.; Tomsovsky, M.; Mrazkova, M.; Gabrielova, S. Phytophthora cactorum causing bleeding canker of common beech, horse chestnut, and white poplar in the Czech Republic. Plant Pathol. 2009, 58, 394. [CrossRef]

12. Pernek, M.; Županić, M.; Diminić, D.; Cech, T. Vrste roda Phytophthora na bukvi i topolama u Hrvatskoj (Phytophthora species on beech and poplars in Croatia). Šumar. List 2011, 135, 130-137. (In Croatian)

13. Keča, N.; Milenković, I.; Keča, L. Mycological complex of poplars in Serbia. J. For. Sci. 2015, 61, 169-174. [CrossRef]

14. Jung, T.; Blaschke, H.; Neumann, P. Isolation, identification and pathogenicity of Phytophthora species from declining oak stands. Eur. J. For. Path. 1996, 26, 253-272. [CrossRef]

15. Jung, T. Beech decline in Central Europe driven by the interaction between Phytophthora infections and climatic extremes. For. Pathol. 2009, 39, 73-94. [CrossRef]

16. Jung, T.; Blaschke, H.; Oßwald, W. Involvement of soilborne Phytophthora species in Central European oak decline and the effect of site factors on the disease. Plant Pathol. 2000, 49, 706-718. [CrossRef]

17. Stamps, D.J.; Waterhouse, G.M.; Newhook, F.J.; Hall, G.S. Revised Tabular Key to the Species of Phytophthora; Mycological Papers 162; CAB International Mycological Institute: Kew, UK, 1990; pp. 1-28. ISBN 0851986838.

18. Jung, T.; Cooke, D.E.L; Blaschke, H.; Duncan, J.M.; Oßwald, W. Phytophthora quercina sp. nov., causing root rot of European oaks. Mycol. Res. 1999, 103, 785-798. [CrossRef]

19. Belbahri, L.; Moralejo, E.; Calmin, G.; Oszako, T.; Garcia, J.A.; Descals, E.; Lefort, F. Phytophthora polonica, a new species isolated from declining Alnus glutinosa stands in Poland. FEMS Microbiol. Lett. 2006, 261, 165-174. [CrossRef] [PubMed]

20. Jung, T.; Burgess, T.I. Re-evaluation of Phytophthora citricola isolates from multiple woody hosts in Europe and North America reveals a new species, Phytophthora plurivora sp. nov. Persoonia 2009, 22, 95-110. [CrossRef] [PubMed]

21. Hong, C.X.; Gallegly, M.E.; Richardson, P.A.; Kong, P. Phytophthora pini Leonian resurrected to distinct species status. Mycologia 2011, 103, 351-360. [CrossRef] [PubMed]

22. Nechwatal, J.; Bakonyi, J.; Cacciola, S.O.; Cooke, D.E.L.; Jung, T.; Nagy, Z.Á.; Vannini, A.; Vettraino, A.M.; Brasier, C.M. The morphology, behaviour and molecular phylogeny of Phytophthora taxon Salixsoil and its redesignation as Phytophthora lacustris sp. nov. Plant Pathol. 2013, 62, 355-369. [CrossRef]

23. White, T.J.; Bruns, T.; Lee, S.; Taylor, J. Amplification and direct sequencing of fungal ribosomal RNA genes for phylogenetics. In PCR Protocols: A Guide to Methods and Applications; Innis, M.A., Gelfand, D.H., Sninsky, J.J., White, T.J., Eds.; Academic Press: San Diego, CA, USA, 1990; pp. 315-322. ISBN 0123721806.

24. Cooke, D.E.L.; Drenth, A.; Duncan, J.M.; Wagels, G.; Brasier, C.M. A molecular phylogeny of Phytophthora and related oomycetes. Fungal Genet. Biol. 2000, 30, 17-32. [CrossRef] [PubMed] 
25. Tamura, K.; Stecher, G.; Peterson, D.; Filipski, A.; Kumar, A. MEGA6: Molecular Evolutionary Genetics Analysis version 6.0. Mol. Biol. Evol. 2013, 30, 2725-2729. [CrossRef] [PubMed]

26. Jung, T.; Hudler, G.W.; Jensen-Tracy, S.L.; Griffiths, H.M.; Fleischmann, F.; Oßwald, W. Involvement of Phytophthora spp. in the decline of European beech in Europe and the USA. Mycologist 2005, 19, 159-166. [CrossRef]

27. Hong, C.X.; Gallegly, M.E.; Richardson, P.A.; Kong, P.; Moorman, G.W. Phytophthora irrigata, a new species isolated from irrigation reservoirs and rivers in Eastern United States of America. FEMS Microbiol. Lett. 2008, 285, 203-211. [CrossRef] [PubMed]

28. Weiland, G.E.; Nelson, A.H.; Hudler, G.W. Aggressiveness of Phytophthora cactorum, P. citricola I and P. plurivora from European beech. Plant Dis. 2010, 94, 1009-1014. [CrossRef]

29. Rytkönen, A.; Lilja, A.; Werres, S.; Sirkiä, S.; Hantula, J. Infectivity, survival and pathology of Finnish strains of Phytophthora plurivora and Ph. pini in Norway spruce. Scand. J. For. Res. 2013, 28, 307-318. [CrossRef]

30. Yang, X.; Tyler, B.M.; Hong, C. An expanded phylogeny for the genus Phytophthora. IMA Fungus 2017, 8, 355-384. [CrossRef] [PubMed]

31. Kovacs, J.; Lakatos, F.; Szabo, I. The role of Phytophthora species in the decline of Black walnut stands. In Proceedings of the International Scientific Conference on Sustainable Development and Ecological Footprint, Sopron, Hungary, 26-27 March 2012; University of West Hungary Press: Sopron, Hungary, 2012; pp. 1-5.

32. Jankowiak, R.; Stępniewska, H.; Bilański, P.; Kolařík, M. Occurrence of Phytophthora plurivora and other Phytophthora species in oak forests of southern Poland and their association with site conditions and the health status of trees. Folia Microbiol. 2014, 59, 531-542. [CrossRef] [PubMed]

33. Milenković, I.; Keča, N.; Karadžić, D.; Radulović, Z.; Milanović, S.; Tomšovsky, M.; Jung, T. Phytophthora diversity in natural ecosystems in Serbia and Montenegro. Unpublished work. 2018.

34. Jönsson, U. A conceptual model for the development of Phytophthora disease in Quercus robur. New Phytol. 2006, 171, 55-68. [CrossRef] [PubMed]

35. Jönsson, U.; Jung, T.; Rosengren, U.; Nihlgard, B.; Sonesson, K. Pathogenicity of Swedish isolates of Phytophthora quercina to Quercus robur in two different soil types. New Phytol. 2003, 158, 355-364. [CrossRef]

36. Jönsson, U.; Jung, T.; Sonesson, K.; Rosengren, U. Relationships between Quercus robur health, occurrence of Phytophthora species and site conditions in southern Sweden. Plant Pathol. 2005, 54, 502-511. [CrossRef]

37. Brasier, C.M.; Cooke, D.E.L.; Duncan, J.M.; Hansen, E.M. Multiple new phenotypic taxa from trees and riparian ecosystems in Phytophthora gonapodyides - P. megasperma ITS Clade 6, which tend to be high-temperature tolerant and either inbreeding or sterile. Mycol. Res. 2003, 17, 277-290. [CrossRef]

38. Jung, T.; Stukely, M.J.; Hardy, G.E.St.J.; White, D.; Paap, T.; Dunstan, W.A.; Burgess, T.I. Multiple new Phytophthora species from ITS Clade 6 associated with natural ecosystems in Australia: Evolutionary and ecological implications. Persoonia 2011, 26, 13-39. [CrossRef] [PubMed]

39. Corcobado, T.; Cubera, E.; Pérez-Sierra, A.; Jung, T.; Solla, A. First report of Phytophthora gonapodyides involved in the decline of Quercus ilex in xeric conditions in Spain. New Dis. Rep. 2010, 22, 33. [CrossRef]

40. Orlikowski, L.B.; Ptaszek, M.; Rodziewicz, A.; Nechwatal, J.; Thinggaard, K.; Jung, T. Phytophthora root and collar rot of mature Fraxinus excelsior in forest stands in Poland and Denmark. For. Pathol. 2011, 41, 510-519. [CrossRef]

41. Nikić, Z.; Letić, L.; Nikolić, V.; Filipović, V. Procedure for underground water calculation regime of Pedunculate oak habitat in Plain Srem (in Serbian with English summary). Bull. Fac. For. 2010, 101, 125-138. [CrossRef]

42. Huai, W.X.; Tian, G.; Hansen, E.M.; Zhao, W.X.; Goheen, E.M.; Grünwald, N.J.; Cheng, C. Identification of Phytophthora species baited and isolated from forest soil and streams in northwestern Yunnan province, China. For. Pathol. 2013, 43, 87-103. [CrossRef]

43. Hueberli, D.; Hardy, G.S.; White, D.; Williams, N.; Burgess, T.I. Fishing for Phytophthora from Western Australia' s waterways: A distribution and diversity survey. Australas. Plant Pathol. 2013, 42, 251-260. [CrossRef]

44. Hulvey, J.; Gobena, D.; Finley, L.; Lamour, K. 2010: Co-occurrence and genotypic distribution of Phytophthora species recovered from watersheds and plant nurseries of eastern Tennessee. Mycologia 2010, 102, 1127-1133. [CrossRef] [PubMed] 
45. Jung, T.; Chang, T.T.; Bakonyi, J.; Seress, D.; Pérez-Sierra, A.; Yang, X.; Hong, C.; Scanu, B.; Fu, C.H.; Hsueh, K.L.; et al. Diversity of Phytophthora species in natural ecosystems of Taiwan and association with disease symptoms. Plant Pathol. 2017, 66, 194-211. [CrossRef]

46. Nagel, J.H.; Gryzenhout, M.; Slippers, B.; Wingfield, M.J.; Hardy, G.E.St.J.; Stukely, M.J.; Burgess, T.I. Characterization of Phytophthora hybrids from ITS clade 6 associated with riparian ecosystems in South Africa and Australia. Fungal Biol. 2013, 117, 329-347. [CrossRef] [PubMed]

47. Oh, E.; Gryzenhout, M.; Wingfield, B.D.; Wingfield, M.J.; Burgess, T.I. Surveys of soil and water reveal a goldmine of Phytophthora diversity in South African natural ecosystems. IMA Fungus 2013, 4, 123-131. [CrossRef] [PubMed]

48. Reeser, P.W.; Hansen, E.M.; Sutton, W.; Remigi, P.; Adams, G.C. Phytophthora species in forest streams in Oregon and Alaska. Mycologia 2011, 103, 22-35. [CrossRef] [PubMed]

49. Shrestha, S.K.; Zhou, Y.; Lamour, K. 2013: Oomycetes baited from streams in Tennessee 2010-2012. Mycologia 2013, 105, 1516-1523. [CrossRef] [PubMed]

50. Hong, C.X.; Richardson, P.A.; Kong, P. Pathogenicity to ornamental plants of some existing species and new taxa of Phytophthora from irrigation water. Plant Dis. 2008, 92, 1201-1207. [CrossRef]

51. Hong, C.X.; Gallegly, M.E.; Richardson, P.A.; Kong, P.; Moorman, G.W. Phytophthora hydropathica, a new pathogen identified from irrigation water, Rhododendron catawbiense and Kalmia latifolia. Plant Pathol. 2010, 59, 913-921. [CrossRef]

52. Jung, T.; Blaschke, M. 2004: Phytophthora root and collar rot of alders in Bavaria: Distribution, modes of spread and possible management strategies. Plant Pathol. 2004, 53, 197-208. [CrossRef]

53. Orlikowski, L.B.; Trzewik, A.; Orlikowska, T. Water as potential source of Phytophthora citricola. J. Plant Prot. Res. 2007, 47, 125-132.

54. Yang, X.; Hong, C.X. Phytophthora virginiana sp. nov., a high temperature tolerant species from irrigation water in Virginia. Mycotaxon 2013, 126, 167-176. [CrossRef]

55. Yang, X.; Copes, W.E.; Hong, C.X. Phytophthora mississippiae sp. nov., a new species recovered from irrigation reservoirs at a plant nursery in Mississippi. J. Plant Pathol. Microbiol. 2013, 4, 5. [CrossRef]

56. Yang, X.; Richardson, P.A.; Hong, C. Phytophthora $\times$ stagnum nothosp. nov., a new hybrid from irrigation reservoirs at ornamental plant nurseries in Virginia. PLoS ONE 2014, 9, e103450. [CrossRef] [PubMed]

57. Moralejo, E.; Pérez-Sierra, A.; Alvarez, L.A.; Belbahri, L.; Lefort, F.; Descals, E. Multiple alien Phytophthora taxa discovered on diseased ornamental plants in Spain. Plant Pathol. 2009, 58, 100-110. [CrossRef]

58. Hardy, G.S.; Barrett, S.; Shearer, B.L. The future of phosphite as a fungicide to control the soilborne plant pathogen Phytophthora cinnamomi in natural ecosystems. Australas. Plant Path. 2001, 30, 133-139. [CrossRef] 